Illinois State University

ISU ReD: Research and eData

Theses and Dissertations

3-15-2016

\title{
The 1622 Powhatan Uprising and Its Impact on Anglo-Indian Relations
}

Michael Jude Kramer

Illinois State University, mjkrame@ilstu.edu

Follow this and additional works at: https://ir.library.illinoisstate.edu/etd

Part of the European History Commons, Indigenous Studies Commons, and the United States History Commons

\section{Recommended Citation}

Kramer, Michael Jude, "The 1622 Powhatan Uprising and Its Impact on Anglo-Indian Relations" (2016). Theses and Dissertations. 513.

https://ir.library.illinoisstate.edu/etd/513

This Thesis is brought to you for free and open access by ISU ReD: Research and eData. It has been accepted for inclusion in Theses and Dissertations by an authorized administrator of ISU ReD: Research and eData. For more information, please contact ISUReD@ilstu.edu. 


\title{
THE 1622 POWHATAN UPRISING AND ITS IMPACT ON ANGLO-INDIAN RELATIONS
}

\author{
Michael J. Kramer
}

\section{Pages}

On March 22, 1622, Native Americans under the Powhatan war-leader Opechancanough launched surprise attacks on English settlements in Virginia. The attacks wiped out between one-quarter and one-third of the colony's European population and hastened the collapse of the Virginia Company of London, a joint stock company to which England's King James I had granted the right to establish settlements in the New World. Most significantly, the 1622 Powhatan attacks in Virginia marked a critical turning point in Anglo-Indian relations.

Following the famous 1614 marriage of the Native American Pocahontas to Virginia colonist John Rolfe and her conversion to Christianity, English colonists in North America and English policymakers in Europe entertained considerable optimism that other Native Americans could be persuaded to embrace both English culture and the Christian faith. After Opechacanough's surprise attacks, efforts to assimilate Native Americans into the Virginia colony stopped. The attitude on the part of English colonists 
in Virginia and policymakers in England became decidedly antagonistic toward Native Americans, and English colonial authorities engaged in callous Indian policies in the wake of the 1622 Uprising.

The inimical English attitudes toward Native Americans and the ruthless policies of separation from and extermination of Native Americans spread beyond Virginia during the seventeenth century and lasted throughout England's colonial presence in North America. Through primary source material including business records, journals, letters, and broadsheets; as well as the work of eighteenth century historians and modern historians and anthropologists, I intend to establish the lasting impact of the 1622 Uprising on Anglo-Indian relations.

KEYWORDS: Opechancanough, Powhatans, Virginia 
THE 1622 POWHATAN UPRISING AND ITS IMPACT ON ANGLO-INDIAN RELATIONS

MICHAEL J. KRAMER

A Thesis Submitted in Partial

Fulfillment of the Requirements for the Degree of

MASTER OF SCIENCE

Department of History

ILLINOIS STATE UNIVERSITY

2016 
(C) 2016 Michael J. Kramer 
THE 1622 POWHATAN UPRISING AND ITS IMPACT ON ANGLO-INDIAN RELATIONS

MICHAEL J. KRAMER

COMMITTEE MEMBERS:

John Reda, Chair

Linda Clemmons 


\section{ACKNOWLEDGMENTS}

The writer wishes to thank his committee members, Dr. John Reda and Dr. Linda Clemmons for their patience and guidance in every stage of the process that culminates in the completion of this thesis. Thanks also to the various professors in Illinois State University's History Department, whose mentorship supplied the analytical tools necessary to the pursuit of a graduate degree. The staffs at Henricus Historical Park, Jamestown Settlement Living History Museum, and Historic Jamestowne were unfailingly hospitable and accommodating in suggesting resources that helped make completion of this project possible, as well as in providing a glimpse into early colonial life through their detailed reproductions of seventeenth-century Virginia settlements and their painstakingly researched historical interpretations. Gary, Sharon, Chris, Tim, Vicki, Calvin, Katie, Bobby, and James Kramer, and Sue Guillory Cheek served as supportive and perceptive sounding boards for this project. Finally, prompt and generous funding from the Veteran's Administration facilitated the academic training required to attain both an undergraduate and a graduate degree.

M. J. K. 


\section{CONTENTS}

Page

ACKNOWLEDGMENTS $\quad$ i

CONTENTS

FIGURES

CHAPTER

I. EARLY SETTLEMENT, EARLY CONFLICTS, AND THE PEACE OF POCAHONTAS 1

Introduction: Why the 1622 Uprising Matters 1

An Inauspicious Beginning $\quad 8$

The Starving Time and the Peace of Pocahontas 14

Lulling the Tassantassas $\quad 22$

II. THE 1622 UPRISING AND ITS AFTERMATH 32

Two Sermons in London and News From Virginia 32

The Day the Sky Fell $\quad 40$

The English Regroup $\quad 48$

III. SHORT-TERM CONSEQUENCES 56

English Rage Fuels English Policy 56

The Second Anglo-Powhatan War 66

IV. THE FALL OF THE VIRGINIA COMPANY 75 
V. LONG-TERM CONSEQUENCES

Beyond Virginia

91

An Epilogue in Virginia

99

Conclusion

104

REFERENCES

109 


\section{FIGURES}

Figure $\quad$ Page

1. C. Smith Taketh the King of Pamaunkee Prisoner, 1608

2. The massacre of the settlers in 1622 


\title{
CHAPTER I
}

\section{EARLY SETTLEMENT, EARLY CONFLICTS, AND THE PEACE OF POCAHONTAS}

\author{
Introduction: Why the 1622 Uprising Matters
}

Writers of modern U.S. historical surveys tend to mention the three Anglo-

Powhatan Wars, seventeenth-century conflicts between English colonists in Virginia and their Native American allies on one side and the Powhatan confederation of more than 30 Native American tribes on the other, only in passing when they mention them at all. ${ }^{1}$ Scholars writing specifically about the establishment and early development of the Virginia colony generally discuss the wars as parts of a larger narrative. Each of the wars, however, was an important event in its own right. The First Anglo-Powhatan War nearly resulted in the failure of England's colonial venture in the Chesapeake Bay region, the

\footnotetext{
${ }^{1}$ John W. Caughey, John Hope Franklin, and Ernest R. May, Land of the Free: A History of the United States, (New York: Benzinger, Inc., 1966), 56-57, 121; Robert A. Divine, et. al., The American Story, Third Edition, (New York, San Francisco, Boston, London, Toronto, Sydney, Tokyo, Singapore, Madrid, Mexico City, Munich, Paris, Cape Town, Hong Kong, Montreal: Pearson Education, Inc., 2007), 35-36, 39; Paul Johnson, A History of the American People, (New York: HarperCollins Publishers, 1997), 26; William J. Rorabaugh, Donald T. Critchlow, and Paula Baker, America's Promise: A Concise History of the United States, (Lanham, UK, Boulder, CO, New York, Toronto, Oxford: Rowman and Littlefield Publishers, Inc., 2004), 23-25. Caughey, Franklin, and May, in their effort to write a multiracial history of the United States, devoted a section to "Fighting Between Whites and Indians," in addition to their brief mention of the Anglo-Powhatan Wars in their summary of the Virginia Colony's development. Divine, et. al, discuss the Virginia Colony primarily as a business venture, and, touching briefly on the 1622 and 1644 Powhatan attacks on English settlements in Virginia, represent them as efforts to drive the English from the region. Rorabaugh, Critchlow, and Baker give the Anglo-Powhatan Wars short shrift, limiting their discussion of the "starving time," and the 1622 Uprising to one sentence each and neglecting the Third Anglo-Powhatan War entirely. Johnson briefly discusses The Starving Time at the outset of the First Anglo-Powhatan War and does not mention the second or third war at all.
} 
second war altered Anglo-Indian relations, and the Third Anglo-Powhatan War resulted in the breakup of the Powhatan confederacy. ${ }^{2}$

It is my contention that the Second Anglo-Powhatan War, which began with Powhatan war leader Opechancanough's surprise attacks on English settlements in the Virginia colony in March of 1622, had lasting consequences not only in England's colonies in North America, but in England itself. Through analysis of primary source documents including business records, letters, government papers, sermons, and diaries, as well as secondary sources including the work of historians and anthropologists, I intend to demonstrate the significance of this relatively obscure event. American historian Alden T. Vaughan describes the 1622 Uprising as one of the most dramatic and significant events in early American history, largely because of the policy changes that the incident brought about. I intend to demonstrate that the Uprising was in important turning point in relations between English colonists and Native Americans, and that Opechancanough's attacks on English settlements led to a hardening of English attitudes toward Native Americans. Long after England was no longer a colonizing presence in North America, Anglo-American politicians and military leaders would describe Native

\footnotetext{
2 Alfred A. Cave, Lethal Encounters: Englishmen and Indians in Colonial Virginia, (Lincoln, NE: University of Nebraska Press, 2011),75-95, 117-133, 134-136; ; Frederic Gleach, Powhatan's World and Colonial Virginia: A Conflict of Cultures, (Lincoln, NE: University of Nebraska Press, 1997), 128-134, 148-173, 174-199; James Horn, A Land as God Made It, (New York: Basic Books, 2005), 187-193, 268288; Helen C. Rountree, Pocahontas, Powhatan, Opechancanough, Three Indian Lives Changed by Jamestown, (Charlottesville, VA: University of Virginia Press, 2005), 111-128, 166-178, 182-187. In an effort to present the founding of Jamestown and the development of Virginia from a Native American perspective, Rountree devotes significant sections of Pocahontas, Powhatan, Opechancanough: Three Indian Lives Changed by Jamestown, to discussion of the wars. Gleach, also writing largely from a Native American perspective, chronicles Native American interaction with English settlers in Virginia from the founding of the colony in 1606 to the outbreak of Bacon's Rebellion in 1675. Horn limits his focus to Virginia's first 18 years, and therefore does not discuss the Third Anglo-Powhatan War, which began in 1644. Cave addresses the incompatibility of English political and social systems with Native American customs and practices in his 2011 book, and. like Horn, devotes much of his discussion of Anglo-Powhatan conflict to the first two Anglo-Powhatan wars.
} 
Americans as treacherous. Popular perceptions of Native American untrustworthiness would provide Anglo-Americans with an excuse to push Native Americans off lands they craved for themselves as white settlement expanded relentlessly westward. ${ }^{3}$

I rely heavily on twentieth-century American historian and economist Susan Myra Kingsbury's edited collection The Records of the Virginia Company of London, particularly focusing on Virginia Company secretary Edward Waterhouse's 1622 pamphlet "A Declaration of the State of the Colonie and Affaires in Virginia, With a Relation of the barbarous Massacre in the time of peace and League, treacherously executed upon the English by the Infidels, 22 March last," which reflected prevailing English attitudes of anger and antagonism toward Native Americans in the aftermath of Opechancanough's surprise attacks. Waterhouse's declaration is an especially important primary source not only because it recommended a draconian strategy for dealing with Native Americans that Anglo-Americans would follow long after England was no longer an imperial presence in what is now the United States, but because its seems to be the definitive account of the 1622 Uprising. Seventeenth century authors like John Smith and Samuel Purchas relied on Waterhouse's report for their own discussion of the Uprising in their respective books The Generall Historie of Virginia, New England \& The Summer Isles, Together with the True Travels, Adventures and Observations, and a Sea Grammar, and Haklutus Posthumus: or Purchas His Pilgrimes. A century later, the report was a key element of discourse on the 1622 Uprising for eighteenth-century American historians like Robert Beverley and William Stith. The document remains influential in modern

\footnotetext{
${ }^{3}$ Vaughan, “'Expulsion of the Salvages:' English Policy and the Virginia Massacre of 1622," The William and Mary Quarterly, Third Series, V. 35, No. 1 (Jan., 1978), 58.
} 
scholarship. American historians James Horn and Alfred A. Cave, along with American anthropologist Helen C. Rountree lean on it substantially in their own discussions of the attack. $^{4}$

The tendency of seventeenth-century Native Americans to rely on oral rather than written traditions means that my primary sources present Anglo-Indian conflicts predominantly from the English point of view. However, Beverley made an effort to include Powhatan oral traditions in his history of Virginia, and Rountree and Gleach, as anthropologists specializing in Native American studies, also provide some insight into the Powhatan perspective.

According to Waterhouse's report, 347 Virginia colonists were killed in the series of surprise attacks that the Powhatan confederacy launched on English settlements and plantations along the James River. However, Waterhouse's figure was somewhat inflated, because he listed approximately 20 women whom the Powhatans had captured during the attacks and later released as having been killed. ${ }^{5}$ The 1622 Uprising wiped out more than a quarter of Virginia's European population, accelerated the collapse of the Virginia Company of London, initiated an Anglo-Powhatan war that lasted for ten years, and

\footnotetext{
${ }^{4}$ John Smith, The Generall Historie of Virginia, New England \& The Summer Isles, Together with the True Travels, Adventures and Observations, and a Sea Grammar, (Glasgow: James MacLehose and Sons, 1907), 280-291; Samuel Purchas, Haklutus Posthumus: or Purchas His Pilgrimes, V. 5, No. 19, (London, New York, Toronto: Macmillan and Co., Ltd., 1906), 157-164; Robert Beverley, The History of Virginia, in Four Parts, reprinted from the author's second revised edition, 1722, V.1, (Richmond, VA: J.W. Randolph, 1855), 39-41; William Stith, The History of the First Discovery and Settlement of Virginia: Being an Essay towards the General History of this Colony, (Charlottesville, VA.: Reprint Company, 1747), 210-212; Rountree, Pocahontas, Powhatan, Opechancanough, 169-170; Gleach, Powhatan's World and Colonial Virginia, 150-154; Cave, Lethal Encounters, 118-121; Horn, A Land As God Made It, 268-270, 276-278. ${ }^{5}$ Edward Waterhouse, "A Declaration of the State of the Colonie and Affaires in Virginia, With a Relation of the barbarous Massacre in the time of peace and League, treacherously executed upon the English by the Infidels, 22 March last, " in The Records of the Virginia Company of London, Susan Myra Kingsbury ed., (Washington, D.C.: Government Printing Office, 1906), V. 3, 565-571; Smith, The Generall Historie of Virginia, New England \& The Summer Isles, 300.
} 
generated shock and outrage in seventeenth-century England that would fuel English policy changes toward Native Americans. Alden T. Vaughan wrote that prior to the Uprising, English settlers in Virginia had begun to form an integrated society of eastern Virginia's Native Americans and Europeans within English settlements, and many English spokesmen on both sides of the Atlantic favored peaceful and cooperative contact with Native Americans. The policy changes from cooperation and conversion with Native Americans to expulsion of Indians from the vicinity of English and extermination of those who would not be expelled, which the 1622 Uprising brought about, were the event's most significant consequences because they would far outlast the Powhatan confederacy and would extend far beyond Virginia's borders. ${ }^{6}$

In the first chapter of this essay, I provide a brief overview of the early years of English settlement in Virginia, touching briefly on the early outbreak of hostilities between the Powhatans and the new European arrivals. I also examine the period from the end of the First Anglo-Powhatan War in 1614 to the renewal of Anglo-Powhatan hostilities in 1622. During this eight-year period, English policymakers for Virginia on both sides of the Atlantic favored a program of peaceful coexistence, indoctrination in European customs, and instruction in Christianity for the Powhatans.

In my second chapter, I discuss the optimism felt in England during the eight years of peace between the English colonists in Virginia. A sermon preached by Patrick Copland, a Virginia Company chaplain, will reflect the sense of buoyancy that prevailed

\footnotetext{
${ }^{6}$ Vaughan, “'Expulsion of the Salvages': English Policy and the Virginia Massacre of 1622," 58.
} 
among Company investors. I will also examine the sense of astonishment and fury that abounded in England when news arrived that the Powhatans had broken the peace a month before Copland preached his sermon of thanksgiving. I then deal with the 1622 Uprising itself, and the immediate English reaction to the surprise attacks on settlements on the James River.

Chapter Three addresses English policy and attitude changes regarding Native Americans that came about as a result of the Uprising. The Virginia Company and the Council in Virginia promptly abandoned efforts at coexistence with and the conversion to Christianity of Native Americans as a result of the March 22, 1622 attacks, and pursued instead a two-pronged program of partition from and wholesale slaughter of Indians in the Chesapeake Bay region. I also look at the nature of English military action against the Powhatan confederacy during the Second Anglo-Powhatan War, which clearly indicates that English policymakers had completely abandoned any hope of harmonious relations with the region's Native Americans. I argue that, after Opechancanough's attacks, the Powhatan strategy of guerrilla raids on English interests suggested that the Uprising was an attempt to confine the English in Virginia to a small area of settlement, rather than to exterminate them or to make them abandon their colonization project.

Chapter Four covers the events that led King James I to order the investigation in the Virginia Company's management of the Virginia colony that ultimately led to the revocation of the Company's charter. The 1622 Uprising led to the failure of an economic diversification project, in which the Virginia Company had invested heavily. Additionally, the Company's recruitment of new settlers for Virginia strained the war-torn colony's inadequate food resources, creating widespread famine and disease. Internal squabbling 
in the Company, bankruptcy, and the king's animosity would likely have brought about the collapse of the Company in time, but the 1622 Uprising helped expedite that downfall.

My final chapter deals with the long-term and far-reaching impact of the 1622 Uprising on Anglo-Indian relations. The two-pronged strategy of separation from and extermination of Native Americans that English policymakers adopted in response to Opechancanough's attacks on English interests spread beyond Virginia's borders in the seventeenth century and lasted throughout England's presence as a colonizing power in North America.

A note on terms. I sometimes use the word Tassantassa, meaning Stranger, a term that the Algonquian-speaking Powhatan confederacy applied to English settlers in Virginia. I also apply the words mamanatowick, meaning "paramount chief," or "great king," and weroance, meaning "king," or "commander." In general, I use Native American terms sparingly, and primarily in an effort to reflect the Powhatan perspective. Seventeenth century English writer William Strachey added a dictionary of Powhatan terms to his 1612 book The Historie of Travail into Virginia Brittania. Tassantassa appears to be a simplification of vtassantassowagh. The word mamanatowick does not appear in Strachey's supplemental dictionary, but he wrote in The Historie of Travaile that Powhatan's own people applied that designation to him and that it meant "great king." The Algonquian word for "king" appears in Strachey's 
supplemental dictionary as "wiroance," but throughout his narrative, he wrote "weroance," when referring to district chiefs. ${ }^{7}$

\section{An Inauspicious Beginning}

Perhaps the foremost proponent of English colonization efforts in the sixteenth century was clergyman and geographer Richard Hakluyt, who argued that staking a claim to lands on the North American continent would provide convenient bases for fleets of privateers to operate against treasure-laden vessels from Spanish colonies. By depriving their Spanish rivals of treasure from the New World, English privateers would diminish Spain's power. The establishment of English colonies in North America would allow Christian missionaries to distill "the swete and lively liquor of the gospel" in the minds of Native American pagans. Furthermore, colonies in North America would alleviate a growing overpopulation problem in England by allowing superfluous people to settle in fertile and temperate lands "as yet unpossessed by any Christians." Large numbers of colonists could potentially produce goods like wine, oil, silk, fruit, sugar, and salt. In addition, English settlements in America would foster profitable commerce with Indians. Hakluyt's arguments swayed Queen Elizabeth, who sponsored English efforts to establish colonies at Baffin Island off the coast of present-day Canada, Newfoundland, and, most famously, Roanoke Island in North Carolina's Outer Banks. All three ventures were unsuccessful, but a report from English soldier Ralph Lane that the mid-Atlantic region

\footnotetext{
${ }^{7}$ William Strachey, The Historie of Travaile Into Virginia Britannia; Expressing the Cosmographie and Comodities of the Country, Together With the Manners and Customes of the People, (London: The Hakluyt Society, 1849), 79, 48, 190, 26-36.
} 
could produce an abundance of wine, oil, flax, resin, pitch, and sugar elicited high hopes for the region that English explorer and courtier Sir Walter Raleigh had named Virginia. ${ }^{8}$

The death of Queen Elizabeth in 1603 and the succession of King James I did not, by any means, signal the demise of English colonial ventures. In April, 1606, James I granted charters to the Virginia Company of Plymouth and the Virginia Company of London, which divided the North American coast into two overlapping spheres of influence. The Virginia Company of Plymouth, made up of merchants and financiers from Bristol, Exeter, and smaller West Country ports, was granted the right to settle an area stretching from the Chesapeake Bay to the coast of present-day Maine. The Virginia Company of London, comprised of London merchants and investors, was granted the right to found settlements between present-day North Carolina and New York, and it was the London Company that sponsored the settlement of Jamestown. The colonists were to pursue a policy of trading with Native Americans as soon as possible, but not to trust the local Indians or to rely on them for subsistence. According to 1606 instructions from King James I to the Virginia Company, conversion of Native Americans was to be affected not through force and cruelty, but through fairness and generosity. Instructions from the Virginia Company of London to the first group of prospective Virginia colonists exhorted them not to offend Native Americans they encountered if such offense could be avoided. On the other hand, the London Company seems to have acknowledged that hostility between English settlers and Native Americans was a distinct possibility,

\footnotetext{
${ }^{8}$ Richard Hakluyt, Leonard Woods, and Charles Deane, A Discourse Concerning Western Planting, Written in the Year 1584, (Cambridge, UK: John Wilson and Son, 1877), 59, 10; Richard Hakluyt and John Winter Jones, Divers Voyages Touching the Discovery of America and the Islands Adjacent, (London: The Hakluyt Society, 1850), 9; Horn, A Land as God Made It, 37-41.
} 
especially once the latter group realized that the newcomers had come to the Chesapeake not merely to trade, but to colonize the region. Any demonstration of European firearms in front of the region's Native Americans was to be performed only by the most experienced English marksmen, because inept shooting would cause Native Americans to "think the Weapon not so terrible and thereby will be bould to Assaillt you."9

In December, 1606, three ships, under the overall command of Captain Christopher Newport and supplied with cargos of glass beads and copper to facilitate trade with Native Americans, sailed from London on a trans-Atlantic voyage that would end somewhere in the Chesapeake Bay region to establish an English colony there. In addition to their cargos of trade goods, the Susan Constant, the Godspeed, and the Discovery carried a total of 144 sailors and prospective settlers. Bickering among the expedition's leaders began long before the little fleet reached the Chesapeake. Captain John Smith, the son of a yeoman farmer who had attained gentleman status through distinguished military service, was too forthright in his advice to his highborn colleagues, Edward Maria Wingfield and Bartholomew Gosnold, who accused him of attempting to foment a mutiny. Smith arrived in Virginia in chains, and was freed only when orders

\footnotetext{
${ }^{9}$ Horn, A Land as God Made It, 50; Cave, Lethal Encounters, 24-25; King James I, “Articles, instructions and order made, sett down and established by Us the twentieth day of November in ye year of our raigne of England, France and Ireland the fourth, and of Scotland the fortieth, for ye good order and Government of the two several Colonies and Plantations to be made by our Loving Subjects, in the Country commonly called Virginia and America, between 34 and 45 degrees from the equinoctial Line," in The Jamestown Voyages Under the First Charter, 1606-1609, V. 1, Philip L. Barbour ed., (Cambridge, U.K.: The Hakluyt Society, 1969), 43; Council for Virginia, "Certain Orders and Directions Conceived and Set Down the tenth Day of December in the Year of the Reign of our Soverain Lord King James of England France \& Ireland the fourth and of Scotland the fortieth by his majesties Counsel for Virginia for the better Government of His Majesties Subjects both Captains Soldiers Marriners and Others that are now bound for that Coast to Settle his Majesties first Colony in Virginia there to be by them Observed as Well in their passages thether by Sea as after their arrival and Landing there." in Barbour ed., The Jamestown Voyages, V. 1, 51-52.
} 
from the Virginia Company of London, which had been sealed until the ships arrived in North America, named him one of seven members of the first Council in Virginia. ${ }^{10}$ Smith's release and appointment to Virginia's first governing body did not restore amicable relations between himself and his fellow councilors, if such bonhomie between the parties had ever existed. The aristocratic president of the Council, Thomas Maria Wingfield, sneered openly at Smith, declaring that while the latter was a gentleman in Virginia, any gentleman in England would scorn the thought of being Smith's companion. Smith despised Wingfield in turn, accusing him of hoarding communal food stores for his own use. The other councilors apparently detested both parties, as well as each other. One councilor, George Kendall, was executed for mutiny and Wingfield himself was deposed and shipped back to England under arrest. John Smith was gravely wounded in a powder explosion while he was on a trading expedition in 1609, and returned to England. Smith himself asserted that his powder bag accidentally caught fire while he was asleep, but also wrote that, upon his return to Jamestown, former Council president John Ratcliffe and secretary to the Council in Virginia Gabriel Archer had planned to have him murdered in his bed. Thinking better of the scheme, the conspirators instead sent him back to England under guard where according to Ratcliffe, he would answer charges of unspecified misdemeanors "whereof I persuade me he can scarcely clear himself from great imputation of blame." 11

\footnotetext{
${ }^{10}$ Horn, A Land as God Made It, 55-56.

${ }^{11}$ Edward Maria Wingfield, "A Discourse of Virginia," in Jamestown Narratives: Eyewitness Accounts of the Virginia Colony, the First Decade, Edward Wright Haile ed., (Champlain, VA., RoundHouse, 1998), 189; Smith, The Generall Historie of Virginia, New England \& The Summer Isles, 91, 193-194; John Ratcliffe, "Letter to Salisbury, 4 October 1609," in Haile ed., Jamestown Narratives, 354.
} 
After an initial attack on an English landing party at the mouth of Chesapeake Bay, repelled when the attacking Native Americans "had spent their arrows and felt the sharpness of our shot," early relations between English settlers and the local Native Americans appear to have been fairly convivial. Archer's report on Captain Christopher Newport's 1607 exploration of the James River was full of references to Native American hospitality and the eagerness of the tribes that Newport's party encountered to trade food for English copper and beads. Newport and his party appear to have attempted to convince the tribes that they were in the region merely to trade, not to establish a permanent settlement. ${ }^{12}$

Construction of fortifications at Jamestown gave the region's Native Americans a clear indication, however, that the new European arrivals had not come merely to trade, but to settle. A test of English strength came before Newport's expedition returned. About 200 Paspaheghs, Quiyoughcahonnocks, Wayanocks, Appamattucks, and Chiskiacks assaulted the fort, nearly overwhelming the English defenders until cannon fire from the ships anchored in the James River repelled the attack. The tribes involved in the attack were those whose land was closest to Jamestown, and were therefore most likely to have concerns about new competition for the land's resources. Although all of the tribes involved in the attack were part of the Powhatan confederacy, they appear to have acted independently. In the summer of 1607, after the fort at Jamestown was completed, the Powhatan confederacy's paramount chief, or mamanatowick, Wahunsenacawh, more

\footnotetext{
${ }^{12}$ George Percy, "Observations gathered out of a discourse of the plantation of the southern colony in Virginia by the English, 1606. Written by that honorable gentleman, Master George Percy," in Haile ed., Jamestown Narratives, 90; Gabriel Archer, "A relation of the discovery of our River from James Fort into the main, made by Captain Christofer Newport, and sincerely written and observed by a gentleman of the colony," in Haile ed., Jamestown Narratives, 103-114.
} 
commonly known to modern historians as Powhatan for the town in which he was born, made friendly overtures to the colonists and ordered the subject tribes in the vicinity to cease their hostilities. Smith noted that the colonists of Jamestown, in spite of having completed their fortifications, were in dire straits when the Powhatans made their offers of peace to the settlement. Council member Batholomew Gosnold died of a famineinduced illness that also left fellow councilors John Ratcliffe and John Martin grievously ill, and bickering among Jamestown's leaders had led to Wingfield's deposition as president and Kendall's removal from the Council and subsequent execution. The time seems to have been ideal for Powhatan to mass his warriors to wipe out the squabbling, starving colonists. Instead, the Powhatans supplied the surviving settlers with grain and bread, just as autumn brought an abundance of edible migrating wildfowl to the region. ${ }^{13}$ Given the mutual antipathy among the Virginia colony's leaders, it is not surprising that whatever amity existed between English settlers and Powhatans did not last long. The Powhatans' penchant for seizing any tool that came within their reach as payment for their hospitality rankled with the settlers, and the colonists' incessant and ever-increasing demands for food rankled with the Powhatans. Relations between the two groups became increasingly strained, and by 1610 had degenerated into armed conflict. Powhatan pursued a strategy of containing the settlers in their forts, killing any who ventured out to forage or trade, and starving them into submission. ${ }^{14}$

\footnotetext{
${ }^{13}$ Archer, "A relation of the discovery of our River from James Fort into the main," in Haile, ed., Jamestown Narratives, 115; Rountree, Pocahontas, Powhatan, Opechancanough, 57-59; Smith, A True Relation of Such Occurrences and Accidents of Note as Happened in Virginia, (Boston: Wiggin and Lunt, 1866), 13-14.

${ }^{14}$ Rountree, Pocahontas, Powhatan, Opechancanough, 111-115.
} 


\section{The Starving Time and the Peace of Pocahontas}

The colony narrowly survived the first Anglo-Powhatan War, which lasted from 1610 to 1614 . At the outset of the war, starvation forced the colony's governor, Sir Thomas Gates, to order an evacuation of Jamestown. John Smith, who had returned to England in 1609 but plainly had kept abreast of affairs in Virginia long after his departure, wrote that during the winter of 1609-1610, only 60 settlers survived out of 500. Smith, an exceptionally outspoken man both in his personal dealings and in his writing, was characteristically graphic in his description of the desperate plight of the settlers at Jamestown during the infamous Starving Time, writing that, after food stores ran out, starving settlers resorted to digging up corpses and stewing them with salt and herbs. In one incident that may have begun as a domestic dispute, one man allegedly killed his wife, salted her corpse and gradually consumed it. ${ }^{15}$

Only chance saved the colony, as the fleet carrying the settlers down the James River for the first leg of a voyage back to England encountered an inbound flotilla carrying Gates' replacement, Thomas West, Lord de la Warre. The inbound ships were laden with munitions, supplies, and 300 new settlers. Had de la Warre's ships encountered a Spanish blockade outside of Chesapeake Bay, or broken up in a hurricane in the West Indies, Gates may have completed his abandonment of Jamestown, drastically altering the future of European settlement in North America. ${ }^{16}$

But no Spanish blockade or Caribbean storm prevented de la Warre from sailing into the Chesapeake and ordering Gates back to Jamestown. The colony did not thrive in

\footnotetext{
${ }^{15}$ Cave, Lethal Encounters, 78-79; Smith, The Generall Historie of Virginia, New England \& The Summer Isles, 204.

${ }^{16}$ Cave, Lethal Encounters, 78-79.
} 
the next four years, but it had survived its closest call. In 1611, the Virginia Company commissioned Sir Thomas Dale to establish a second English settlement at Henrico, roughly 50 miles up the James River from Jamestown. English colonists were able to trade with the Patawomecks, an outlying nation of the Powhatan confederacy. In April, 1613, Powhatan's favorite daughter Amonute, visited friends in a Patawomeck town ruled by the weroance, or commander, Iopassus. Amonute is celebrated in modern American folklore by a pet-name that her father had given her: Pocahontas. English shipcaptain Samuel Argall was in Patawomeck territory on a trading expedition and, receiving word of Pocahontas' presence, concluded that a paramount chief's favorite daughter would make a valuable hostage. Accordingly, Argall enlisted Iopassus in a plan to abduct her. Iopassus persuaded Pocahontas to join him and one of his wives in a walk along the riverfront. Seeing Argall's ship, Iopassus' wife professed an interest in touring the vessel. Iopassus played his part by forbidding his wife to board the ship unless another woman accompanied her. Pocahontas was conveniently the only woman available. The party toured the ship, dined with Argall, and spent the night aboard. When the party prepared to disembark the next morning, Argall had Pocahontas detained and declared her to be a hostage for the return of eight Englishmen whom he claimed were prisoners of the Powhatans, along with a cache of pilfered European weapons. ${ }^{17}$

The abduction of Pocahontas set Anglo-Powhatan peace negotiations in motion. Powhatan's devotion to his daughter appears to have been genuine, because his response to the news of her abduction was an immediate plea to Argall to treat her well. He followed his entreaty with the return of seven English captives, along with the delivery of

\footnotetext{
${ }^{17}$ Rountree, Pocahontas, Powhatan, Opechancanough, 126-127.
} 
tools, guns, and a canoe filled with corn, plus a promise to deliver 500 bushels of corn in compensation for any tools or weapons that were broken or missing. Virginia Company secretary Ralph Hamor wrote that Gates, the colony's acting governor, would not believe the remainder of the weapons that he claimed the Powhatans had stolen from English settlements had been damaged or misplaced, and demanded their return. In the meantime, Pocahontas remained a hostage at Jamestown. ${ }^{18}$

Sometime during her captivity, Pocahontas was moved to Henrico, where she met tobacco planter John Rolfe and received instruction in Christianity from Reverend Alexander Whitaker, the settlement's minister. Rolfe is known today not only for his 1614 marriage to Pocahontas, but for his efforts to introduce a profitable commodity to Virginia's economy. Arriving in Virginia with de la Warre's expedition, he began planting a strain of tobacco from seeds that he had brought from the West Indies. Sweeter and more fragrant than the tobacco that was native to the Chesapeake Bay region, it was more palatable to European smokers and quickly became Virginia's first cash crop. Indeed, Virginia's dependence on tobacco as its sole profitable export eventually became a bone of contention between the Virginia Company and King James I. ${ }^{19}$

When Powhatan did not reply to Gates' demand for the return of missing weapons and tools, Dale forced the issue in March, 1614, nearly a year after Pocahontas' capture. Hamor described Dale's expedition up the Pamunkey (now the York) River, where Powhatan's "chiefest habitations" lie. Pocahontas and 150 well-armed settlers

\footnotetext{
${ }^{18}$ David A. Price, Love and Hate in Jamestown: Pocahontas, John Smith, and the Start of a New Nation, (New York: Vintage Books, 2005), 150-151; Ralph Hamor, A True Discourse of the Present State of Virginia, (Richmond, VA.: The Virginia State Library, 1957), 7.

${ }^{19}$ Hamor, A True Discourse of the Present State of Virginia, 24; Martha W. McCartney, Virginia Immigrants and Adventurers, 1607-1635, A Biographical Dictionary, (Baltimore: Genealogical Publishing Company, 2007), 606.
} 
accompanied the expedition, whose purpose was to force the Powhatans to either fight or restore the remainder of the missing tools and weapons. ${ }^{20}$

At Matchcot, one of Powhatan's principle towns, Dale's party found themselves facing some 400 Powhatans, armed with bows and arrows. The colonists went ashore peacefully, but the tension on both sides must have been palpable as each party waited for the other to make a hostile move. The arrival of two of Pocahontas' brothers broke the impasse as they pressed Dale to allow them to see their sister. When Powhatan arrived, with his brother and successor Opitchapam, peace negotiations began in earnest. In a 1614 letter to a friend known only by the initials D.M., Dale wrote that Pocahontas, given a choice between being restored to her father's people or remaining with her English captors, expressed disgust at Powhatan's avarice, saying that if her father had truly prized her, he would not have valued her less than old swords, muskets, and axes, and she would therefore remain with the English, who loved her. ${ }^{21}$

In June, 1614, Whitaker reported in a letter to his cousin, a Master Gouge, that his star Native American pupil had married "an honest and discreet English gentleman, Master Rolfe," and that furthermore, Pocahontas had openly rejected Powhatan religious practices, had been baptized as a Christian, and had taken the name Rebecca. Judging from his letter to Dale, the colony's newly-appointed governor, Rolfe seemed to have found the chance to convert Pocahontas to European culture and beliefs more of a motivating factor in his decision to marry her than any sort of romantic attachment. He also appears to have been fending off criticism of his marriage of a Native American,

${ }^{20}$ Hamor, A True Discourse of the Present State of Virginia, 7.

${ }^{21}$ Hamor, A True Discourse of the Present State of Virginia, 10; Sir Thomas Dale, "To the Reverend and Most Esteemed Mr. D.M., at His House at F. Ch. In London," in Haile ed., Jamestown Narratives, 844. 
insisting in his letter to Dale that he acted not out of carnal desire, as some of his English critics claimed, but for the good of the colony, his own salvation, the glory of God, and the conversion of an unbeliever. ${ }^{22}$

Pocahontas' decision to remain among the English settlers was an indication that she may have come to identify with her captors, having been abducted at the age of 16 , when she could have learned new languages and new customs and practices fairly readily. Her confinement, the rigid schedule that her English custodians imposed, and their continuous insistence that Native American practices were wrong amounted to an immersion in European culture. Such an immersion at an impressionable age could well have had a lasting psychological impact. Additionally, she would have found herself farther removed from the paramount chief and the center of Powhatan power with each new succession among her own people, while her English captors treated her as a person of unique consequence. ${ }^{23}$

Whatever her reasons may have been for remaining among the English and marrying an Englishman, there is no doubt that Pocahontas' choice was a momentous one. To the settlers in Virginia and policymakers in England, she may have embodied the triumph of English beliefs and practices over a Native American culture they had always perceived to be less enlightened than their own. ${ }^{24}$ Where her abduction led to an Anglo-

\footnotetext{
${ }^{22}$ Alexander Whitaker, "To My Very Dear and Loving Cousin Master Gouge, Minister of the Black Friars in London," in Haile ed., Jamestown Narratives, 848; John Rolfe, "The copy of the gentleman's letters to Sir Thomas Dale, that after married Powhatan's daughter, containing the reasons moving his thereunto," in Haile ed., Jamestown Narratives, 851.

${ }^{23}$ Rountree, Pocahontas, Powhatan, Opechancanough, Three Indian Lives Changed by Jamestown, 131132; Smith, The Generall Historie of Virginia, New England \& The Summer Isles, 239-240.

24 "A Counterbalste to Tobacco," in The Workes of the Most High and Mightie Prince James by the Grace of God, King of Great Britaine, France and Ireland, Defender of the Faith, \&c, (London: Robert Barker and John Bill, 1616), 214-215; Smith, A True Relation of Such Occurrences and Accidents of Note as Happened in Virginia, 34; Strachey, A History of Travaile into Virginia Britania, 52-53. There is ample evidence to indicate that English writers of the early seventeenth century considered Native American
} 
Powhatan truce, her conversion and marriage to Rolfe ended the First Anglo-Powhatan War, ushering in an eight-year lull in Anglo-Powhatan hostilities that is commonly known as The Peace of Pocahontas. ${ }^{25}$

Because of their success in Anglicizing one of Virginia's Indians, Englishmen on both sides of the Atlantic Ocean held out hope that they could indoctrinate all of the region's Native Americans into European culture, effectively training them to become obedient subjects of the English crown. Indeed, the first clause of the treaty that officially ended the First Anglo-Powhatan War specified that the Powhatans would consider themselves subjects of King James I. Perhaps Dale decided that interracial marriage was a key to training Native Americans in subservience to English culture and the English crown, because in March, 1615, he attempted to emulate John Rolfe's example. He dispatched Captain Ralph Hamor on a diplomatic mission to Powhatan at Matchcot in hopes of arranging a marriage between himself and the mamanatowick's youngest daughter. $^{26}$

Powhatan seems to have received Hamor cordially, perhaps because Hamor's party had come bringing gifts of copper, glass beads, fishhooks, combs, and knives. Hamor appears to have been somewhat abrupt in his manner, coming to the point of his

culture inferior to their own. In "A Counterblaste to Tobacco," James I reviled Native Americans as "godless and slavish," and as "aliens from the holy Covenant of God," while denouncing their customs as "barbarous and beastly." In his 1608 account of his capture by Opechancanough, John Smith was simultaneously appreciative and condescending of Powhatan's reception of him at Werecomoco, writing that "it drave me into admiration to see such state in a naked Salvage." Strachey, while consistently referring to Native Americans as "Indians," rather than such pejoratives as "Salvages," or "heathens," was unable to refrain from describing Powhatan as "such a barbarous and uncivill prince," or censuring the Powhatan acceptance of polygamy as "sensuall heathenism."

${ }^{25}$ National Park Service, "Pocahontas: Her Life and Legend," Historic Jamestowne, accessed February 19, 2016, http://www.nps.gov/jame/learn/historyculture/pocahontas-her-life-and-legend.htm.

${ }^{26}$ Hamor, A True Discourse of the Present State of Virginia, 42. 
mission after sharing only a ceremonial pipe. In this case, Powhatan's family feeling appears to have overcome his covetousness, because he refused offers of "treble the price of his daughter, in beades, Copper, Hatchets and many other things more useful for him," and sent Hamor back to Dale with the mild rebuke that "I holde it not a brotherly part of your king, to desire to bereave me of two of my children at once."27

In spite of Powhatan's rebuff of an English suitor for a second of his daughters, Anglo-Powhatan relations remained cordial, and efforts to assimilate Native Americans into an English colony continued. In their first meeting in 1619, members of the Virginia General Assembly authorized local officials throughout the colony to obtain Native American children through just means for education in "true religion and civile course of life.” By 1621, the Virginia Company, with help from the Church of England, was actively raising funds to open the College of Henricus, a boarding school for young Native Americans, who would be removed from their tribes for the sort of immersion in European culture that Pocahontas must have experienced. Additionally, the Assembly resolved that small numbers of Powhatan adults could live and work in well-populated English settlements under the provision that "good guarde in the night be kept upon them." The Assembly's general caution against complacency was an understandable one in light of the Anglo-Powhatan hostilities of the very recent past. In a May, 1621 letter to Sir Edwin Sandys, Thorpe, a member of the Council in Virginia, wrote that the Powhatans had increasingly adopted English fashions, and requested that the Virginia

\footnotetext{
${ }^{27}$ Hamor, A True Discourse of the Present State of Virginia, 42.
} 
Company send apparel and household goods for distribution to the Powhatans as gifts. In a 1621 report compiled from various letters from Virginia colonists, Purchas related that Opechancanough took particular pleasure in an English-style house that had been built for him. He displayed it proudly to both hisown people and to strangers, Purchas wrote, and seemed especially fascinated by the locks and the keys, "locking and unlocking the doores, sometimes a hundred times in a day." ${ }^{28}$ Purchas appears to have found Opechancanough's constant manipulation of his locks and keys amusing as an indicator of his supposed primitive nature.

While Purchas chuckled with Anglocentric condescension at Opechancanough's simplicity, he could have interpreted the Powhatan war-chief's obsession as a determination to master every piece of European technology at his disposal. And Opechancanough could very well have been playing a role for the benefit of his English observers: the wide-eyed primitive, spellbound by the workings of a seventeenth-century security device. Later events overwhelmingly support the idea that the Powhatan warleader was actively attempting to foster the same sense of complacency against which the colony's General Assembly had cautioned settlers, and his assumption of the role of an untutored barbarian overcome with the wonders of European technology was almost certainly part of that effort.

\footnotetext{
${ }^{28}$ Virginia General Assembly, "The First Assembly of Virginia, held July 30, 1619," Colonial Records of Virginia, Mark C. Orton, Thomas Strong ed., (Richmond, VA: R.F. Walker, Superintendent Public Printing, 1874), 20-21; Janie Mae Jones McKinley,, The Cultural Roots of the 1622 Indian Attack: Richard Pace and Chanco Save Jamestown, (Silva, NC: Catch the Spirit of Appalachia, Inc., 2011), 96; George Thorpe and John Pory, "A Letter to Sir Edwin Sandys, May 15 and 16, 1621," in Kingsbury ed., The Records of the Virginia Company of London, V. 3, 446; Purchas, Haklutus Posthumus: or Purchas His Pilgrimes, 153.
} 


\section{Lulling the Tassantassas}

Even as Englishmen on both sides of the Atlantic hoped to transform purportedly barbaric Native Americans into loyal and productive subjects of the King of England, Powhatan aspired to incorporate the new arrivals, whom the Powhatans called Tassantassas, or Strangers, into the empire he had established on Virginia's coastal plain. Powhatan appears to have decided that the Tassantassas, with their iron tools and terrifying weapons, were worth having as allies against inland enemies like the Siouxanspeaking Monacans who lived in the foothills of the Blue Ridge mountains. After Smith's first visit to Powhatan at his seat at Werewocomoco in 1608 , as a prisoner of a hunting party that Opechancanough had led, the mamantowick declared a bond of friendship with the English explorer. Smith, writing of the encounter in his 1624 book The Generall Historie of Virginia, New England \& the Summer Isles, Together with The True Travels, Adventures and Observations, and A Sea Grammar, related that Powhatan would "for ever esteeme him as his sonne Nantaquoud.” The mamanatowick also dispatched Smith back to Jamestown to send him "two great gunnes and a grindstone." ${ }^{29}$

To Smith, the product of a patriarchal English culture, the relationship of a father to a son would have implied that of a superior to a subordinate. However, in many Algonquian-speaking Native American groups like the nations that made up the Powhatan confederacy, the role of a father was one of open-handed generosity, and Powhatan's "adoption" of Smith could easily be interpreted as a promise of future largesse. There is less ambiguity in Powhatan's parting instructions to Smith. In directing

\footnotetext{
${ }^{29}$ Rountree, Pocahontas, Powhatan, Opechancanough, 73-74; Smith, The Generall Historie of Virginia, New England \& The Summer Isles, 102.
} 
Smith to obtain cannons and a grindstone for his use, the mamanatowick seems as imperious as a European monarch assigning an errand to a trusted courtier. In his 1608 book A True Relation of Such Occurrences and Accidents of Note as Happened in Virginia, Smith wrote that Powhatan had declared him a weroance, an unequivocal effort to make him subordinate to the mamanatowick and, by incorporating an English leader into his political structure, to begin absorbing the English colony into his empire. ${ }^{30}$

William Strachey's observations of Powhatan suggest that of the seven deadly sins that are so prominent in Christian teaching, the mamanatowick's principle vice was avarice. In his in-depth study of Virginia's geography, climate, natural resources, and indigenous communities, Strachey noted that Powhatan kept a house a mile from one of his principle towns of Orapax, which he filled with treasure that included "skynnes, copper, perle, and beads, which he storeth upp against the tyme of his death and buryall." Later in his narrative, Strachey described Powhatan's effort to control the flow of European goods, particularly copper, into his paramount chiefdom. The mamanatowick would buy the goods for a few measures of grain, resell them to his neighbors at many times what he had paid, and always reserve a plentiful amount of the goods for himself. ${ }^{31}$ Such efforts to manage the distribution of European trade goods among his own people suggest an effort on Powhatan's part to assimilate those goods into the region's economic system as he strove to absorb the traders into the local Native American political system.

Because Powhatan, who had inherited six chiefdoms in the York River drainage and the James River basin, expanded his influence to more than 30 chiefdoms by the time

\footnotetext{
${ }^{30}$ Smith, A True Relation of Such Occurrences and Accidents of Note as Happened in Virginia, 51.

${ }^{31}$ Strachey, The Historie of Travaile Into Virginia Britannia, 54, 103-104.
} 
the first English colonists arrived, it is understandable that he thought he could exert similar influence over the new arrivals and their technology. However, there were those close to Powhatan's seat of power who concluded that his efforts to assimilate the Tassantassas had not been and would not be successful. Foremost among these dissenters was the war-chief Opechancanough.

Opechancanough's background merits closer examination because of the prominent role he would play in colonial affairs through the 1620s and 1630s and even after his death in 1646 . His exact relationship to Powhatan is unclear. He may have been a full brother, a half-brother, or even a cousin. ${ }^{32}$ As one of Powhatan's heirs in a matrilineal kinship system, Opechancanough became war-chief upon the former's death in 1618, dividing the paramount chiefdom with another "brother," Opitchapam, who became peace-chief. Whether or not he shared power with Powhatan as he would with Opitchapam, Opechancanough seems to have wielded considerable influence by the time the first European settlers sailed up the James River. Gabriel Archer, one of Jamestown's original settlers, described him as The King of Pamunkey or Pamaunche, one of Powhatan's original inherited chiefdoms and a core of the paramount chiefdom. ${ }^{33}$

\footnotetext{
${ }^{32}$ Hamor, A True Discourse of the Present State of Virginia, 53; Smith, The Generall Historie of Virginia, New England \& The Summer Isles, 260; Strachey, The Historie of Travaile Into Virginia Britannia, 57; Rountree, The Powhatan Indians of Virginia, Their Traditional Culture (Norman, OK: University of Oklahoma Press, 1989), 188-189; Gleach, Powhatan's World and Colonial Virginia, 141-142; Beverley, The History of Virginia, 48. Hamor, Smith, and Strachey all referred to Opechancanough and Opitchapam as Powhatan's brothers. However, Rountree notes that the term "son," in the Powhatan kinship system could apply to a nephew and the term "brother" was often applicable to the son of a mother's sister. Likewise, Gleach writes that a "brother," could be a cousin by European reckoning. Beverley wrote that, according to Native Americans of the region, Opechancanough was not related to Powhatan at all, but had come to the region from far to the southwest. Given that Opechancanough was apparently second in line to succeed Powhatan, this conjecture is unlikely, but suggests that he was not a popular figure among Virginia Indians in the eighteenth century.

${ }^{33}$ Gabriel Archer, "A relation of the discovery of our river from James Fort into the main, made by Captain Christofer Newport, and sincerely written and observed by a gentleman of the colony," in Haile ed., Jamestown Narratives, 113.
} 
Eighteenth century Virginia historian Robert Beverley described Opechancanough as a man "of large stature, noble presence, and extraordinary parts." 34

Beverley's depiction of Opechancanough as a tall, athletic man fits with Gabriel Archer's representation of Powhatan males as "proper, lusty, straight men, very strong." And a contemporary illustration of John Smith taking Opechancanough prisoner shows a somewhat undersized Englishman scuffling with a well-built Native American at least a head taller than himself. ${ }^{35}$

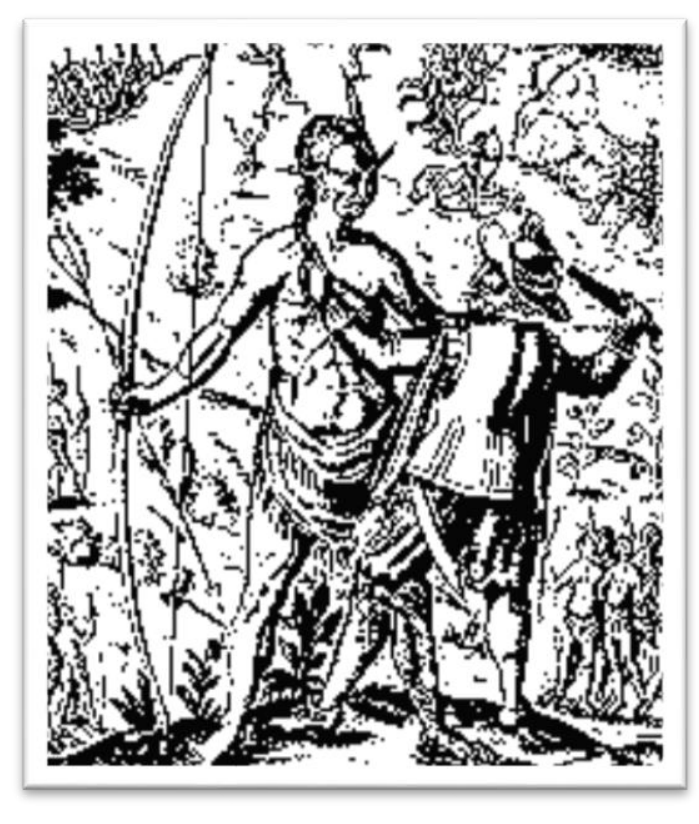

Figure 1: "C. Smith Taketh the King of Pamaunkee Prisoner, 1608." Engraved by Robert Vaughan for John Smith's General Historie, (London, 1624).

Archer, in his account of Newport's exploration of the James River, painted a portrait of Opechancanough as a man who was at least conscious of his dignity. As he received Newport's party, Archer wrote Opechancanough "so set his countenance striving

\footnotetext{
${ }^{34}$ Beverley, The History of Virginia, in Four Parts, V. 1, 48.

${ }^{35}$ Archer, "A Brief Description of the People," in Haile, Jamestown Narratives, 123.
} 
to be stately as to our seeming he became fool." ${ }^{36}$ It is a strong possibility that Archer, a Cambridge-educated gentleman from Essex, could have been looking at Opechancanough not only through an Anglocentric lens, but also through a worldview in which dignity was the exclusive privilege of English aristocrats. Where Archer found Opechancanough's assumption of an authoritative manner somewhat ridiculous, it is also easy to see the warchief as a man of considerable pride. Affronts to that pride would have rankled, and Opechancanough would have remembered the humiliation of an incident in 1608 when Smith, fearing for the safety of himself and his trading party, produced a pistol and took him hostage. Smith related that Opechancanough was "neare dead with feare," but it is just as easy to imagine the proud war-chief shaking with outrage at having been made a prisoner in his own village. Opechancanough never forgave the Tassantassas for the incident and, as later events would demonstrate, he possessed the patience to spend years nursing a grudge and planning his revenge before taking action. ${ }^{37}$

Opechancanough had been steadily gaining political power during the last years of Powhatan's life. By 1614, he had become "one that can as soone (if not sooner) as Powhatan commaund the men." With Powhatan's death and Opitchapam's ascension in 1618, it is likely that Opechancanough became mananatowick in all but name. Native American author Linwood Custalow, a grandson of Mattaponi Chief Daniel Webster Custalow, and American author Angela L. Daniel, wrote that Opitchapam was a weak

\footnotetext{
${ }^{36}$ Archer, "A relation of the discovery of our river from James Fort into the main, made by Captain Christofer Newport, and sincerely written and observed by a gentleman of the colony," in Haile ed., Jamestown Narratives, 113.

${ }^{37}$ Smith, The Generall Historie of Virginia, New England \& The Summer Isles, 166; Rountree, Pocahontas, Powhatan, Opechancanough, 104.
} 
leader and Beverley described him as "a Prince far short of the Parts of Oppechancanough." 38

There exists a distinct possibility that Powhatan initially tolerated the Tassantassas within his domain because their choice of a patch of mosquito-infected marshland where the water was brackish for much of the year as a settlement site, combined with their apparent inability to forage and hunt, demonstrated that the newcomers were too inept to survive. As the Tassantassas slowly starved in the midst of natural abundance, he, Powhatan, could acquire the iron tools, the copper, and the firearms that the wealthy, but feckless foreigners had brought. But Powhatan had not reckoned with a demographic explosion in England over the last half of the sixteenth century that more than doubled the country's population by 1600. Early colonists did indeed starve, but an overpopulated England had what may have seemed to apprehensive Native American observers to be an inexhaustible supply of replacement personnel. ${ }^{39}$

Opechancanough, as Powhatan's primary battle commander, had a front row seat for English colonization efforts from the first landing at Jamestown, and had witnessed the arrival of more English ships bringing more English colonists for a decade before the mamanatowick's death. It is difficult to imagine the war-leader watching Tassantassa settlements claim forests where he had hunted deer and turkeys with anything other than alarm.

\footnotetext{
${ }^{38}$ Hamor, A True Discourse of the Present State of Virginia, 53.

${ }^{39}$ Rountree, Pocahontas, Powhatan, Opechancanough, 54-57; William Bruce Wheeler, Susan Becker, Lorri Glover, Discovering the American Past: A Look at the Evidence, Volume I: to 1877, Seventh Edition, (Boston: Wadsworth, Cengage Learning, 2012), 59; Linwood Custalow, Angela L. Daniel, The True Story of Pocahontas: The Other Side of History, (Golden, CO: Fulcrum Publishing, 2007), 87; Beverley, The History of Virginia, V. 1, 34.
} 
By 1620, Chickahominies, Wayanocks, and Paspaheghs had been forced off land adjacent to English settlements, while more English settlers had begun to occupy land belonging to the Appamattucks, Arrohatecks, Powhatans, Kecoughtans, Quiyoughcohannocks, and Warraskoyaks. Opechancanough would almost certainly have bristled with resentment at the strong-arm tactics of English settlers, who often traded for or outright pilfered Native American food supplies at gunpoint. He could very well have viewed with suspicion the English practice of trading directly with Powhatan tributary groups like the Patawomecks. Not only did that trade represent a circumvention of the mamanatowick's authority, it also suggested an English colonial policy of weakening indigenous groups by fomenting dissent. Opechancanough, the Native American equivalent of a career soldier and a veteran of Powhatan's campaigns of expansion, was probably experienced enough to recognize a divide-and-conquer strategy when he saw one. The most ominous development, however, may have been the establishment of an English boarding school for young Native Americans. To Opechancanough, that school, and the indoctrination of Powhatan children in English customs and beliefs meant the subversion of Powhatan culture. ${ }^{40}$

For the first few years that he shared the paramount chiefdom with Opitchapam, Opechancanough pursued a policy of conciliation regarding the Tassantassas. Upon Powhatan's death and their accession in 1618, the brothers jointly confirmed the peace treaty that Powhatan and Sir Thomas Dale had negotiated in 1614. Opechancanough had already supported the Tassantassas in a 1616 conflict with the Chickahominies, who had refused to pay the settlers tribute in violation of the 1614 treaty that had ended the First

\footnotetext{
${ }^{40}$ Horn, A Land as God Made It,267; McKinley, The Cultural Roots of the 1622 Indian Attack, 97.
} 
Anglo-Powhatan War, although he could have been acting out of self-interest, since his intervention in the Anglo-Chickahominy clash allowed him to absorb the remnants of the previously autonomous Chickahominies into the Powhatan confederacy. ${ }^{41}$ When the region's Native Americans proved reluctant to turn their children over to the Tassantassas for fostering, Opechancanough worked out a compromise in 1619 with newly appointed governor Sir George Yeardley whereby the English would provide Native American families houses and fields near their settlements in order to instruct children without separating them from their parents. ${ }^{42}$

Opechancanough was undoubtedly aware of the tactical problems he faced in any potential military engagement against the English. His warriors could not prevail in a pitched battle against English armor and muskets. They could not storm a well-defended settlement in the teeth of cannon fire and protective palisades. And they had no answer for the ships that could sail the English up and down rivers to raid Native American food supplies and fields. Only a surprise attack could possibly defeat the interlopers, and in order to gain that surprise, he first had to gain his enemies' trust and insert his warriors into their midst. While Opechancanough could well have seen the new English policy of educating Native Americans as a threat to his own culture, he must have been delighted at the opportunity it presented to infiltrate English settlements.

Opechancanough was able to outface a rumor that had come to Yeardley from a weroance of the Accomacs in 1621 that he planned to use the pretext of the ceremonial

\footnotetext{
${ }^{41}$ Horn, A Land as God Made It, 264; Cave, Lethal Encounters, 106.

${ }^{42}$ Horn, $A$ Land as God Made It, 264.
} 
interment of Powhatan's remains to assemble warriors for an assault on English settlements and plantations. In the fall of 1622, new Virginia governor Sir Francis Wyatt sent Thorpe, who had built the house in which Opechancanough had taken such seeming pleasure, as an ambassador to the war-leader. Opechancanough's declaration to Thorpe that his traditional practices were wrong and he wished to be instructed in Christianity was potentially an enormous triumph for the English policy of assimilation and conversion of Native Americans for the obvious reason that a fast way to convert a population is to convert its rulers. And when one of his greatest warriors, Nemmatanow, known to the English colonists as "Jack of the Feathers" for the garish costume he habitually wore, was killed in a scuffle with two settlers, Opechancanough assured a messenger Wyatt had sent to discuss the incident that although he grieved for his fallen weroance, Anglo-Powhatan peace was so firmly established that the sky would fall before he broke it. ${ }^{43}$

The progress that Opechancanough made in lulling his English neighbors into the sense of complacency that achieving an element of surprise demanded becomes clear when one studies the gradual relaxation of English policy. In a 1618 proclamation, Governor Samuel Argall curtly forbade any settler to teach the use of firearms to Native Americans "on pain of death." Argall, a veteran of the First Anglo-Powhatan War and Pocahontas' abductor, was clearly skeptical that the Peace of Pocahontas would hold, and

\footnotetext{
${ }^{43}$ Council in Virginia, "Letter to Virginia Company of London, January 20, 1622/3," in Kingsbury ed., The Records of the Virginia Company of London, V. 4, 10; Council in Virginia, "Letter to Virginia Company of London, January 1621/2," in Kingsbury ed., The Records of the Virginia Company of London, V. 3, 584; Smith, The Generall Historie of Virginia, New England \& The Summer Isles, 280.
} 
also issued an edict against commerce or familiarity with Native Americans "lest they discover our weekness." Under Yeardley, the First Virginia Assembly confirmed Argall's sanction against settlers training Native Americans in the use of firearms. The Assembly's members were more specific than Argall in declaring that providing Native Americans with guns, powder, or ammunition, or training them in the use of firearms was treason to the colony and punishable by hanging. Although the Assembly passed a law allowing small numbers of Indians to live in well-populated settlements, English suspicion of Native Americans was plain in the members' insistence that Indian families live apart from their white neighbors. But by 1622, Opechancanough's mask of compliance and docility had so relaxed English security measures that settlers had begun teaching Indians the use of firearms, which would have been a capital offense under Argall's regime, and had employed them to hunt deer and fowl for the settlements. English colonists opened their homes to Native Americans, who often dined at English tables and slept in English bed-chambers. So confident were the colonists of peace between themselves and the Powhatans, Smith wrote, that settlers began to establish plantations wherever they found promising veins of unoccupied land. Those outlying plantations would be especially vulnerable to Opechancanough's warriors. ${ }^{44}$

\footnotetext{
${ }^{44}$ Samuel Argall, "Governor Argall: Proclamations or Edicts, May 18, 1618," in Kingsbury ed., The Records of the Virginia Company of London, V. 3, 93; Virginia General Assembly, "The First Assembly of Virginia, held July 30, 1619," in Orton and Strong ed., Colonial Records of Virginia, 25-26; Smith, The Generall Historie of Virginia, New England \& The Summer Isles, 269-280.
} 


\section{CHAPTER II}

\section{THE 1622 UPRISING AND ITS AFTERMATH Two Sermons in London and News From Virginia}

On April 18, 1622, members of the Virginia Company of London and their wives filed into Bow Church in the London suburb of Cheapside for a special service in thanksgiving for the safe arrival in Virginia of nine ships carrying approximately 800 settlers. The mood was clearly a festive one, with the stockholders and their wives dressed in their finest. Virginia Company chaplain Reverend Patrick Copland preached an enthusiastic sermon in which he expressed his own and the congregation's joy that the Company's ships had surmounted dangers at sea from pirates, storms, and shoals. A veteran missionary who had traveled to India and Japan during his prior appointment as an East India Company chaplain, Copland had firsthand experience of the hazards associated with seventeenth century sea travel. During a 1617 voyage to India, he was aboard the Royal James when a typhoon near the coast of Japan wrecked the Unicorn, a ship from the convoy in which the Royal James sailed. His personal experience with storms and shipwrecks allowed him to provide details that secondhand accounts would likely have omitted, and it is easy to imagine his listeners' rapt expressions as he related that "sailors are neither amongst the living, nor yet amongst the dead as, having but a few inches of plank between them and death, they hang between both, ready to offer up their 
souls to every flaw of wind and billow of water wherein they are tossed." 45

Travelers to Virginia who survived the hazards of an ocean voyage faced more dangers upon arrival, Copland said, and "some perished for want of comfortable provision," while "others were killed by the Bowes and Arrows of the Savage." 46 While Virginia Company shareholders in England did not share the mortal peril that had faced settlers in America, Copland pointed out that the members' fortunes had been at risk, asking "what masse of money have you buried in that Plantation?" Many of the stockholders must have despaired, he speculated, of ever seeing a return on their investments, and at least some of his listeners could well have come to regret investing in the Company's colonial venture. ${ }^{47}$

Improvements in navigation had mitigated the dangers that travelers to Virginia faced during a trans-Atlantic voyage, Copland preached, because of the "fittest season of the yeare for a speedie passage, being now farre better knowne then before," while Native American hostility and starvation were hazards of the past. Between Virginia's settlers and the indigenous Native Americans, there had been for several years "a happie league of peace and amity, soundly concluded and faithfully kept," while new colonists arriving there could count on "plenty of good and wholesome provisions," and a "faire Inne for receiving and harboring of strangers." 48 The Virginia Company's stockholders, Copland assured his listeners, had weathered the economic dangers that had threatened their

\footnotetext{
${ }^{45}$ Edward Duffield Neill, Memoir of Rev. Patrick Copland, Rector Elect of the First Projected College in the United State, New York: Charles Scribner \& Co., 1871, 52-53; Patrick Copeland and Peter Pope, Virginia's God be thanked, or A sermon of thanksgiving for the happie success of the affayres in Virginia this last yeare, (London: William Sheffard and John Bellamy, 1622), 3.

${ }^{46}$ Copland and Pope, Virginia's God be thanked, 6.

${ }^{47}$ Copland and Pope, Virginia's God be thanked, 11

${ }^{48}$ Copland and Pope, Virginia's God be thanked, 9-10.
} 
fortunes. Thanks to an economic diversification project undertaken at the behest of King James I and spearheaded by influential Virginia Company investor Sir Edwin Sandys, the Virginia colony had overcome its dependence on tobacco as a cash crop and would produce an abundance of "Corne, Wine, Oyle, Lemons, Oranges, Pomegranats, and all manner of fruites pleasant to the eye and wholesome for the belly," as well as silk, flax, hemp, cotton-wool, iron, and copper. Within a few years, Copland predicted, Company investors could hope for a return of "double, treble, yea, I may say of tenfold for one."49

Career missionary that he was, Copland had a particular interest in the education and conversion of the non-Christian peoples he had encountered in his travels. During his service with the East India Company, he had educated and converted an Indian from around the Bay of Bengal, who took the name Peter Pope and would later transcribe Copland's sermon for publication. Returning to England from India in 1621, Copland had encountered settlers in the West Indies who were bound for Virginia. Learning from these travelers of a scarcity of churches and schools in Virginia, he applied for and received a new position as a chaplain for the Virginia Company of London. He began raising funds at home and solicited donations from his contacts in the East India Company abroad to help open a university at Henrico, where in 1620 Virginia governor Sir George Yeardley had set aside 10,000 acres of land for the purpose. Although he had not yet visited Virginia, Copland expected that he would soon be bound for the colony, having been elected rector of a school dedicated to instructing and converting Native Americans. It is easy to imagine the joy that animated his features and lent timbre to his voice as he delivered a report he had received in correspondence from George Thorpe, overseer of

${ }^{49}$ Copland and Pope, Virginia's God be thanked, 12-13. 
the college lands, that Virginia's Native Americans "seeme to groane under the burden of the bondage of Satan, and to want nothing but meanes to be delivered." Opechancanough himself had "willingly acknowledged that theirs was not the right way, desiring to be instructed in ours. $" 50$

It is extremely likely, in light of the news from the colony in which the Virginia Company's stockholders had invested, that a reception followed the service, replete with the finest available food, drink, and entertainment. As the stockholders and their wives, dressed in their finest, ate, drank, and danced, they were blissfully unaware of the turn affairs in Virginia had taken nearly a month before.

In November, 1622, Reverend John Donne, the dean of London's St. Paul's Cathedral, preached another sermon to Virginia Company members: a sermon whose tone contrasted sharply with Copland's optimism. Where Copland portrayed Virginia's Native Americans as eager for instruction in the Christian faith, Donne denounced them as enthusiastically and unrepentantly pagan, justly detestable for the delight they purportedly took in deceit, treachery, and violence. "As they multiply assassinations on princes and massacres upon people, deamonium habent, they have a devil." ${ }^{, 51}$

Although Patrick Copland and John Donne preached to essentially the same congregants, the prevailing moods among their listeners would have certainly been dramatically different. As Copland exhorted Virginia Company shareholders to offer a prayer of thanksgiving for the safe arrival of ships and colonists in Virginia, it is likely

\footnotetext{
${ }^{50}$ Neill, Memoir of Rev. Patrick Copland, 22-30, 47-48; Copland and Pope, Virginia's God be thanked, 2829.

${ }^{51}$ John Donne, "Sermon CLVI. Preached to the Virginian Company, 1622." In The Works of John Donne, D.D., Dean of St. Paul's, 1621-1631, With a Memoir of His Life, V. 6, Henry Alford ed., (London: John W. Parker, 1839), 236.
} 
that a few investors offered another such prayer for the brightening economic prospects of which he preached. Donne's sermon came in the wake of much grimmer news than Copland's, and would certainly have created a bleaker atmosphere in St. Paul's Cathedral. The same Virginia Company shareholders who had rubbed their hands together in anticipation of the profits that Copland had predicted probably shuddered not only at Donne's description of the "flood of blood," that had broken over Virginia, but also at the prospect of seeing their fortunes wash away in that flood. ${ }^{52}$

Donne seems to have been aware of his listeners' fiscal concerns, but does not appear to have been particularly interested in alleviating those apprehensions. God had ordained, he preached, that the temporal kingdom of Virginia would have "not ease, not abundance; nay, nothing at all yet.” But settlers in Virginia and Virginia Company investors could still do great service to the eternal kingdom, which Donne presented as far more important than any temporal kingdom. The plantation of Virginia, Donne preached, would "redeem many a wretch from the jaws of death," or "from the hand of the executioner," meaning that Christian settlement among non-Christian Native Americans would ultimately rescue Native American souls that would otherwise have perished..$^{53}$

In addition to providing the opportunity to convert Native Americans to Christianity, Donne saw merit in the plantation of Virginia in that it cleared England of "idle persons, and the children of idle persons," and found them employment. Moreover,

\footnotetext{
${ }^{52}$ Donne, "Sermon CLVI. Preached to the Virginian Company, 1622," in Alford ed., The Works of John Donne, 229.

${ }^{53}$ Donne, "Sermon CLVI. Preached to the Virginian Company, 1622," in Alford ed., The Works of John Donne, 230.
} 
Donne said in a brief acknowledgment of his congregation's collective economic worries, the commodities that had reached Europe from Virginia in the 15 years of the colony's existence had already made the plantation a mark for the envy of England's Spanish and French rivals. In short, the colony was a worthwhile endeavor even in the face of the mortal danger that Virginia's settlers faced and the financial ruin that menaced Virginia Company investors after the 1622 Uprising. ${ }^{54}$

Donne's advocacy of laboring to convert Native Americans to European values and practices was representative of a policy that Virginia's governing body, the Council in Virginia, had pursued for the past eight years. But in the aftermath of the Uprising, his call for cooperation and conversion in the face of hostility and hardship appears to have been drowned out in the chorus of incensed voices baying for retribution. Those voices would influence English policy toward Native Americans not only in Virginia, but in New England as well.

Between Copland's April sermon and Donne's discourse in November, word had reached England of a coordinated Powhatan attack on English settlements along the James River. The news came in the form of a letter from the colony's governor, Sir Francis Wyatt, to the Virginia Company. The Powhatans, Wyatt wrote, had "under the Colour of unsuspected amity," attempted "to have Swept us away through owte the whole lande had it nott plesed god of his abundante mercy to prevent them in many places."55

\footnotetext{
${ }^{54}$ Donne, "Sermon CLVI. Preached to the Virginian Company, 1622," in Alford ed. The Works of John Donne, 231.

${ }^{55}$ Council in Virginia, "A Letter to the Virginia Company of London," in Kingsbury ed., The Records of the Virginia Company of London, V. 3, 612.
} 
It is not difficult to hold up Patrick Copland as a victim of one of history's great ironies. But in the absence of updates from Virginia, which did not reach England until two months after he preached his sermon, his vision of a prosperous future for English colonization efforts in North America appeared well-founded. The first years of the Virginia colony's existence, Copland conceded, had been discouraging, to say the least. But Virginia's first hard years seemed to be in the past.

The "happie league of peace and amity," between Virginia's English colonists and the nations of the Powhatan confederacy that Copland described in his sermon was unequivocally at an end. ${ }^{56}$ New arrivals in Virginia would find themselves, contrary to Copland's assurances, fighting for their lives against hostile natives, as well as food shortages that so commonly accompany warfare, and diseases that so commonly accompany food shortages. The economic diversification project in Virginia lay in ruins because of Powhatan destruction of settlers' fields, vineyards, and groves.

William Capps, a representative for Elizabeth City County in Virginia's First General Assembly, succinctly and vividly summed up the astonishment, grief, and despair that many settlers must have felt when he wrote "God forgive me, I thinke the last massacre killed all our Countrie, beside them they killed, they burst the heart of all the rest." ${ }^{57}$ Capps is known to have agitated for the English crown to take control of the colony, and it is possible that he misrepresented popular sentiment in Virginia in an effort to discredit the Virginia Company's management of colonial affairs. Given the relative magnitude of the disaster that had befallen the colony, however, Capps is unlikely to have

${ }^{56}$ Copland and Pope, Virginia's God be thanked, 9.

${ }^{57}$ William Capps, "Letter to Dr. Thomas Winston, March or April, 1623," in Kingsbury ed., The Records of the Virginia Company of London, V. 4, 38. 
exaggerated the shock and apprehension that must have still prevailed among the surviving colonists. That distress and trepidation sailed across the Atlantic Ocean and arrived with news of the assault in mid-June. The Virginia Company's reply to Wyatt's report conveyed the members' extreme grief about events in the colony, and English lawyer and poet Christopher Brooke lamented that "my Passion rent my heart with sorrow for that dyre event" in a poem written in the summer of $1622 .{ }^{58}$

When surviving colonists in Virginia and investors and policymakers in England had recovered from the shockwave that reports of the Uprising had undoubtedly brought, anger followed astonishment and pain. That anger, and an accompanying call for revenge, is manifest in a variety of sources. Virginia Company secretary Edward Waterhouse described the Powhatans as "perfidious and inhumane people," and pronounced the attacks on English settlements to be "contrary to all lawes of God and men, of Nature \&Nations.” English clergyman Reverend Samuel Purchas, who published several volumes reporting on the travels of Europeans to foreign countries, stressed the perceived treachery, cruelty, and savagery of the Powhatans in his exploration of affairs in the Virginia colony. And Christopher Brooke made the transition from shock and grief to loathing and anger in his poem when he wrote of "that Hoast of Hells black brood, Wolves, Tygars, and Tyrants, that have lickt the blood Of Christian Soules." 59

\footnotetext{
${ }^{58}$ Treasurer and Council for Virginia, "Letter to Governor and Council in Virginia, August 1, 1622," in Kingsbury ed., The Records of the Virginia Company of London, V. 3, 666; Christopher Brooke, "A Poem on the Late Massacre in Virginia," in The Virginia Magazine of History and Biography, V. 72, No. 4 (July, 1964), 274.

${ }^{59}$ Edward Waterhouse, "A Declaration of the State of the Colonie and Affaires in Virginia, With a Relation of the barbarous Massacre in the time of peace and League, treacherously executed upon the English by the Infidels, 22 March last, " in Kingsbury ed., The Records of the Virginia Company of London, V. 3, 551; Samuel Purchas, Haklutus Posthumus: or Purchas His Pilgrimes, V. 5, No. 19, (London, New York, Toronto: Macmillan and Co., Ltd., 1906), 157-164; Christopher Brooke, "A Poem on the Late Massacre in Virginia," in The Virginia Magazine of History and Biography, V. 72, No. 4 (July, 1964), 276.
} 
Both Waterhouse and Brooke presented the Powhatans, and perhaps Native Americans in general, as less than human. Waterhouse specifically referred to the Powhatans as "beasts," and Brooke highlighted their perceived bestiality throughout his poem. The implications of dehumanizing terms in writing or speaking of the Powhatans becomes particularly ominous when one considers that the use of dehumanizing language has, throughout history, often been a prelude to a genocidal campaign.

\section{The Day the Sky Fell}

On the morning of March 22, 1622, at English settlements and plantations along the James River from the site of present-day Richmond to Hampton Roads, where the river empties into the Chesapeake Bay, Indians from various tribes of the Powhatan confederacy approached colonists in a friendly fashion. Many brought deer, turkeys, and fish to trade for European goods. Some entered the homes of settlers and joined them for breakfast, while others worked alongside the colonists at their daily chores. By this time, such visits had become routine. Wyatt's policy since his arrival in Virginia seems to have been to encourage such interaction, and Native Americans often borrowed settlers' tools or boats. As the Powhatans ate with their Tassantassa hosts, haggled with Tassantassa traders, or worked alongside Tassantassa farmers, they are likely to have kept one eye on the position of the sun. Edward Waterhouse compiled a report of what happened next from interviews with and letters from surviving Virginia colonists. The resulting document, "A Declaration of the State of the Colony and Affaires in Virginia," is the most detailed account of an attack that left 347 settlers dead or missing. Waterhouse's report 
provided a list of English casualties in each district, a useful resource in that it supplied information as to which areas of the colony were hardest hit. ${ }^{60}$

At the prearranged time, the Powhatans, who had approached the settlements and plantations with no weapons showing, picked up whatever tools or weapons were at hand. A colonist weeding his tobacco field may have had his skull split by a hoe while another, entertaining a Powhatan breakfast guest, could have been run through with a carving knife or impaled on a cooking spit. The stroke was so sudden, Waterhouse wrote, that "few or none discerned the weapon or blow that brought them to destruction." 61

Waterhouse expressed the belief that the slaughter of colonists would have been universal had it not been for a timely warning. A converted Indian living with a tobacco planter named Richard Pace, had been approached by his brother the previous day. The brother had informed him of the coming attack and urged him to kill Pace. Instead, the Powhatan convert warned Pace, who rowed across the James River at midnight to warn Wyatt at Jamestown. The scene Waterhouse depicted conjures a host of images: the Christianized Indian hiding his horror at the threat to a man he presumably saw as his benefactor, Pace's frantic departure to cross a three-mile wide river in the darkness, a rumpled and bleary-eyed Wyatt roused from bed to receive Pace's news and act on it. Waterhouse did not give the name of the Christianized Indian who warned Pace. But an April, 1623 letter to the Virginia Company from the Council in Virginia mentioned a man named Chauco, who had revealed Opechancanough's plot. Opechancanough seems to

\footnotetext{
${ }^{60}$ Horn, A Land as God Made It, 269; Waterhouse, "A Declaration of the State of the Colony and Affaires in Virginia," in Kingsbury ed., The Records of the Virginia Company of London, V. 3, 565-571.

${ }^{61}$ Waterhouse, "A Declaration of the State of the Colony and Affaires in Virginia," in Kingsbury ed., The Records of the Virginia Company of London, V. 3, 551.
} 
have been unaware of Chauco's purported defection, because the Council reported that the latter had recently come to Jamestown as part of an embassy to the English.

Eighteenth-century Virginia historian William Stith was perhaps the first writer to corrupt the name Chauco into Chanco, the name by which the young Native American convert is probably best known today. While a Native American youth who was employed at the plantation of one William Perry indeed warned Perry's neighbor, Richard Pace, of the coming attack and Pace subsequently warned Wyatt, Chauco or Chanco was probably an amalgam of several Powhatans who informed English neighbors of the imminent danger. ${ }^{62}$

Wyatt appears to have acted decisively on short notice, securing the fort, and repulsing a Powhatan attack in the morning. The distance from Jamestown to settlements like Henrico, nearly 50 miles, was too great for any messengers Wyatt may have dispatched to raise the alarm in time for colonists in those areas to prepare for the coming assault. Wyatt's primary concern seems to have been defending the center of the colony's government from a surprise attack, because the private plantation of Martin's Hundred,

\footnotetext{
${ }^{62}$ Waterhouse, "A Declaration of the State of the Colony and Affaires in Virginia," in Kingsbury ed., The Records of the Virginia Company of London, V. 3, 555; Council in Virginia, "Letter to Virginia Company of London, April 4, 1623," in Kingsbury ed., Records of the Virginia Company of London, V. 4, 98; William Stith, The History of the First Discovery and Settlement of Virginia, 212; Rountree, Pocahontas, Powhatan, Opechancanough, 169-170.
} 


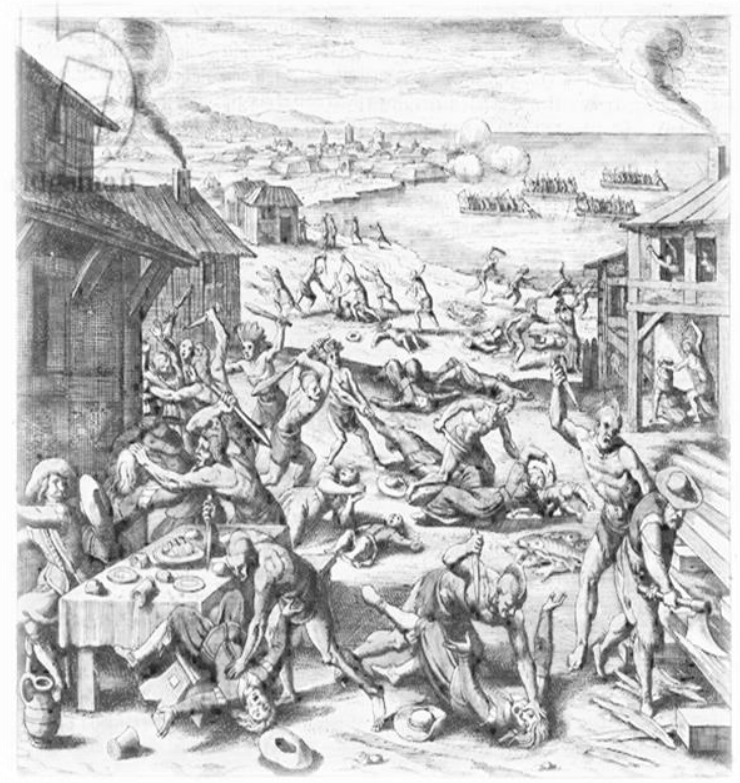

just seven miles from Jamestown, had clearly received no warning of a coming assault.

\author{
Waterhouse reported that more than \\ 70 colonists died at Martin's Hundred, but \\ presumed the deaths of 20 women who had \\ merely been taken prisoner, and lived \\ among the Powhatans after the Uprising. ${ }^{63}$
}

Figure 2: "The massacre of the settlers in 1622," engraved by Matthaus Merian the Elder for America, Part XIII, German edition, (Frankfurt, 1628).

At Berkley's Hundred plantation, near present-day Richmond, George Thorpe had received a warning of the attack much like Chanco's warning to Pace. Thorpe had built the English-style house in which Opechancanough took such seeming delight. He had been Wyatt's messenger to the Powhatans, the overseer of the lands that Henrico College occupied, and a leading proponent of integrating Native Americans into colonial English society. He seems to have firmly believed he had earned his Powhatan neighbors' goodwill many times over and disregarded the warning, unable to believe he could be in any danger. Thorpe apparently persisted with that belief right up until the Powhatans killed him. Opechancanough may have specifically wished to make an example of this

\footnotetext{
${ }^{63}$ Waterhouse, "A Declaration of the State of the Colony and Affaires in Virginia," in Kingsbury ed., The Records of the Virginia Company of London, V.3, 570; Fausz, "The Missing Women of Martin's Hundred," American History, V. 33, No. 1 (March, 1998), 57-58; Rountree, Pocahontas, Powhatan, Opechancanough, 168.
} 
leading agent of English cultural imperialism, because Thorpe's corpse was singled out for "barbarous despights and foules scornes ... as are unbefitting to be heard by any civill eare." Because of Thorpe's missionary work among the Powhatans, Waterhouse declared that he had "gained a Crowne of endlesse blisse, and is assuredly become a glorious Martyr."

Other notable English casualties included three other members of the Council in Virginia: Captain Nathaniel Powell, Captain Samuel Macock, and John Berkeley. At Falling Creek, a settlement about 60 miles from Jamestown and the site of Berkeley's plantation, the entire English population of 27 men, women, and children perished. The name of John Rolfe was not listed among the casualties of the uprising, but it is known that he had returned to Virginia in 1619 after Pocahontas' death in England, and he is known to have died in 1622. But while the possibility exists that Rolfe perished in the Uprising, it is unlikely that Waterhouse would have omitted so famous a colonist from the casualty list he had so painstakingly compiled. ${ }^{64}$

Although early spring would seem to have been a poor time to begin a military campaign due to a lack of food supplies and the need to plant crops for the coming year, Opechancanough saw distinct advantages in waging war during the season that Virginia's Algonquin-speaking Indians called cattapeuk, because the Tassantassas would not be able to retaliate against the warriors' loved ones. Powhatan families traditionally dispersed from their populations centers at the end of winter to fish and forage. The end of winter meant that travel would have been easier for the messengers Opechancanough

\footnotetext{
${ }^{64}$ Waterhouse, "A Declaration of the State of the Colony and Affaires in Virginia," in Kingsbury ed., The Records of the Virginia Company of London, V. 3, 552-553. 565-571.
} 
needed to send in coordinating the attack, while the debilitating heat of summer was months away. The season of taquitock, which corresponded to the European autumn, would have also been an opportune time for the Powhatans to initiate conflict with the English because it was another cycle in which families dispersed on fishing and foraging expeditions. Opechancanough's apparent concern for the time of year in which he launched his attack strongly suggests that he had not planned on an extended campaign, hoping that he would achieve his objectives before summer, when his warriors would have had to battle heat and pestilence as well as English muskets. ${ }^{65}$

According to Waterhouse, the Powhatans did not distinguish between man or woman, adult or child in their killing of settlers. This disregard for age or sex was almost certainly an innovation learned from the English, because Powhatans traditionally killed only adult male enemies while abducting or adopting women and children. Conversely, George Percy, who served as acting President of the Council in Virginia from September, 1609 to May, 1610, related a 1610 incident in which English soldiers executed an unspecified number of captured Paspehegh children by throwing them into the James River and shooting at their bobbing heads. 66

Where Europeans of the early seventeenth century waged war primarily for territorial acquisition, Native Americans of the region engaged in armed conflict to avenge insults or to boost their populations through abduction and adoption, although

\footnotetext{
${ }^{65}$ McKinley, The Cultural Roots of the 1622 Indian Attack, 101; Rountree, Pocahontas, Powhatan, Opechancanough, 168.

${ }^{66}$ Rountree, The Powhatan Indians of Virginia, 127; George Percy, “A True Relation of the proceedings and occurrents of moment which have hap'ned in Virginia from the time Sir Thomas Gates was shipwrack'd upon the Bermudes anno 1609, until my departure out of the country, anno 1612", in Haile ed., Jamestown Narratives, 510.
} 
control of resources also was a key factor in Native American warfare. With the different understanding of military objectives inherent in their respective cultures, it is not surprising that the Powhatans would misinterpret how the English interlopers would respond to the coordinated assault of March $22 .{ }^{67}$

Waterhouse's contention that the slaughter of Virginia colonists would have been universal had it not been for Pace's warning to Jamestown was almost certainly incorrect. The 1622 Uprising was a fairly representative example of Powhatan tactics and strategy. Powhatan had employed the tactic of infiltrating an enemy's settlement with a friendly approach before attacking in his conquest of the Piankatanks, undertaken before the disruptive arrival of English settlers in his newly-won empire. In contrast to Waterhouse's suggestion that the Powhatans had intended nothing less than the murder of every European man, woman, and child in the region, Opechancanough's objective was probably merely to flex his military muscle or to demonstrate to the Tassantassas that they had worn out their welcome. Helen C. Rountree and James Horn speculate that Opechancanough's ultimate goal was to drive the surviving settlers back to Europe. According to Alfred A. Cave however, he may have hoped to confine the English to a small territory and end English efforts to convert the Powhatans to Christianity. Frederic Gleach asserts that Opechancanough valued the colonists for their trade goods, and only wished to discipline them, not expel them. It is possible that Opechancanough sought to contain the colonists to a small area in hopes of triggering a second Starving Time, which would cause the discouraged settlers to simply board ships and return to England, as they

\footnotetext{
${ }^{67}$ Rountree, The Powhatan Indians of Virginia, 127.
} 
had so nearly done in 1610 . But it is more likely that he merely wished to end English encroachment on Powhatan land and attempted subversion of Powhatan culture. ${ }^{68}$

The fact that Jamestown, Newport News, Elizabeth City, and plantations on Virginia's Eastern Shore were left untouched during the March 22 attacks lends significant weight to the position that Opechancanough's goal was not the extermination of every European in the region. Opechancanough possessed ample manpower to continue his campaign against the Tassantassas, and the success of his surprise attacks had given him a tactical advantage. While it is not clear what sort of manpower Opechancanough had at his disposal, his main attack force consisted of 500-600 elite Powhatan and Pamunkey warriors and hundreds of auxiliaries. Population estimates of the Powhatan empire from John Smith and William Strachey listed the number of warriors in each of the Powhatan towns. Strachey's estimate of the military strength of each town was generally higher than Smith's whenever the two sources differed, but the total number of warriors in both calculations was between 2,000 and 2,500. They would have had a significant numerical advantage over the surviving Virginia colonists, and weight of numbers has counted as a telling tactical advantage for as long as warfare has existed. In addition, the Powhatans had seized control of the countryside and its resources, gaining another classic tactical advantage by denying those resources to his enemies. However, Native American reluctance to attack fortified positions is likely to have been a factor in Opechancanough's decision not to launch more attacks. Opechancanough simply did not have an answer for English palisades and entrenched

\footnotetext{
${ }^{68}$ Rountree, Pocahontas, Powhatan, Opechancanough, 166; Horn, A Land as God Made It, 274; Cave, Lethal Encounters, 119; Gleach, Powhatan's World and Colonial Virginia, 158.
} 
English artillery, and could never have overrun fortified English enclaves. The assertion that Opechancanough's objective was to either expel or contain the Tassantassas is almost certainly correct. But since Opechancanough never divulged his military aims to his English enemies, whether he conceived his strategy of containment to starve the Virginia colony into submission, as Powhatan so nearly succeeded in doing a decade before, or to modify the colonists' behavior must remain a matter of speculation almost 400 years later. $^{69}$

\section{The English Regroup}

A series of commissions to Hamor and Captain Roger Smith shows that during the month following the attack, Wyatt was ordering the evacuation of outlying settlements like Henrico and Coxendale to the fortified settlements of Jamestown, Elizabeth City, Charles City, and Newport News, effectively placing the colony under martial law. John Smith described the consolidation of Virginia's population as the establishment of an English peninsula between the James and York rivers in the north and south, Chesapeake Bay in the east, and the Chickahominy River to the west. On Henrico Island, Alice Proctor, who had armed her servants and defended her plantation against the Indians, found that she could not hold off Wyatt's order to evacuate to Jamestown. Militia troops reportedly threatened to burn down her house if she did not accompany them, as the Powhatans did after her departure. ${ }^{70}$

Wyatt did not draft his report of the attack to the Company until after April 20.

${ }^{69}$ Cave, Lethal Encounters, 119-120; Horn, A Land as God Made It, 269-270; Rountree; The Powhatan Indians of Virginia, 18.

${ }^{70}$ Smith, The Generall Historie of Virginia, New England \& The Summer Isles, 291-292. 
The delay in reporting to the Company was probably due to Wyatt's need to assess the damage to the colony and regroup the survivors, as well as having to wait until the Sea Flower, the ship that would carry news of the attack back to England, was ready to sail. But it is possible to picture Wyatt as reluctant to admit to his employers that the policy he had supported of peaceful coexistence with the Powhatans had failed in a spectacular fashion. Indeed, the Company's Treasurer and Council began their August reply with something of a dressing-down, rebuking Wyatt for being surprised in a time of known danger, and for dismissing the warning of Opechancanough's hostile designs that he had received the previous year. Wyatt's stupidity in not detecting and suppressing such an open conspiracy, the Company's officers declared, had made him an instrument through which Opechancanough carried out his designs which "the least wisdome or courage suffised to prevent even on the point of execution." ${ }^{.71}$

If Opechancanough had intended to eliminate the colony's European population, as Waterhouse claimed, he would have needed to overrun the fortified English settlements. For that venture to succeed, he would have required the element of complete surprise, which was lost when Richard Pace completed his midnight crossing of the James.

Shortly after the March 22 attacks, Opechancanough had allegedly boasted to a Patawomeck weroance that within two months, there would not be an Englishman left in their country. The weroance subsequently reported the boast to English trader Captain

\footnotetext{
${ }^{71}$ Council in Virginia, "A Letter to the Virginia Company of London, April (after 20), 1622," in Kingsbury ed., The Records of the Virginia Company of London, V. 3, 610-611, Treasurer and Council for Virginia, "Letter to Governor and Council in Virginia, August 1, 1622," in Kingsbury ed., The Records of the Virginia Company of London, V.3, 666.
} 
Raleigh Croshaw who, in a natural course of events, passed the information along to Wyatt and the Council in Virginia. The veracity of the source in which the account of Opechancanough's boast appeared, The Generall History of Virginia, New England \& the Summer Isles, is questionable. Smith, having left Virginia never to return 15 years before completing The Generall History, evidently retained an avid interest in the colony for the rest of his life. It stands to reason that he would have kept abreast of developments in Virginia. But the news he received would of necessity have been secondhand, and would have reflected pro-English, anti-Powhatan biases. Additionally, The Generall History contained events from Smith's time in Virginia that he did not record in A True Relation of Such Occurrences and Accidents of Note as Happened in Virginia. Because The Generall History was published during the Second Anglo-Powhatan War, it is easy to interpret Smith's narrative as part of an English propaganda effort to depict the Powhatans as murderous barbarians. The grim promise that Opechancanough allegedly made could well have represented Smith's portrayal of a bloodthirsty savage. ${ }^{72}$

If Opechancanough assumed that his English opponents would behave like Native American adversaries after a military defeat and withdraw to their home territory, that assumption would indicate a lack of understanding regarding cultural differences, an unlikely oversight in light of the fact that he had as much exposure to Tassantassa ways as his late brother, Powhatan. Such a conjecture would also have shown a failure to appreciate the difficulties of such an evacuation. An ocean separated Virginia's colonists from an overpopulated homeland that would have had no space, and certainly no economic opportunities for them. Indeed, one of the key reasons Donne offered in his

\footnotetext{
${ }^{72}$ Smith, The Generall Historie of Virginia, New England \& The Summer Isles, 298.
} 
sermon at St. Paul's for the continuation of English settlement in Virginia was that the colony would "sweep our streets and wash our doors of idle persons and the children of idle persons," and provide them with productive work. If Virginia's sole purpose were to force England's unemployed to work, Donne added, then that single function was sufficient to justify the colony's continued existence. ${ }^{73}$

While Donne obtained news of the Uprising secondhand, Wyatt had a front-row seat for the event, and drafted the first of the reports that would shock England. His failure to incorporate the Powhatans into the colony he governed and his proximity to hundreds of now-hostile Native Americans do not seem to have diminished Wyatt's commitment to remaining in Virginia. In his April, 1622 letter to the Virginia Company, he requested food to sustain the colonists who were bottled up in their fortified settlements. He requested weapons that would help the colonists defend themselves against Indian attacks. Significantly, Wyatt not only did not ask for a fleet to evacuate the surviving colonists back to Europe, but instead asked the Company to recruit additional settlers and provide them with tools for farming, clearing land, and improving fortifications. Clearly, he did not see evacuating the colony as a viable option. ${ }^{74}$

On the other side of the Atlantic, the Virginia Company demonstrated its members' reluctance to abandon their colonial venture by recruiting hundreds of new settlers, the first of which arrived on the ship bearing the Treasurer and Council for Virginia's reply to Wyatt. The Treasurer and Council did not snub these new colonists in

\footnotetext{
73 Donne, "Sermon CLVI. Preached to the Virginian Company, 1622," in Alford ed. The Works of John Donne, 230.

${ }^{74}$ Council in Virginia, "A Letter to the Virginia Company of London, April (after 20), 1622," in Kingsbury ed., The Records of the Virginia Company of London, V. 3, 613-614.
} 
Donne's terms as idle persons to be swept from England's streets and washed from England's doors. Instead, the Company's letter to Wyatt stressed the importance of the new arrivals, giving them a sort of nobility of purpose in declaring that "in the multitude of people is the strength of a kingdom." 75

While potential colonists were not in short supply in England, grain apparently was: not a surprising phenomenon in an overpopulated country. Virginia Company officials confessed that they saw little possibility of satisfying Wyatt's request for additional food with "the publique stock being utterly as you know exhausted." There were undoubtedly many Virginia colonists who questioned whether the addition of hundreds of hungry settlers who would have to exist on dwindling local food stores would strengthen the colony, as the Virginia Company so blithely promised. But if the Company could not assure that the recruited colonists would be well-fed upon their arrival, its members ensured that the new arrivals would be well-armed through their procurement of an assortment of armor and weapons from the arsenal of the Tower of London. It is likely that the members of the Company's council believed that Wyatt could only improve Virginia's economic circumstances by improving the colony's military circumstances. Clearly, Company officials expected the governor to regain the areas that settlers had abandoned in the aftermath of the Uprising, stating that "the replanting of them is of absolute necessity." The recruitment of new settlers appears to have been among Waterhouse's key objectives when he wrote "A Declaration of the State of the Colony and Affaires in Virginia." He lauded Virginia's natural abundance in extravagant

\footnotetext{
${ }^{75}$ Treasurer and Council for Virginia, "Letter to Governor and Council in Virginia, August 1, 1622," in Kingsbury ed., The Records of the Virginia Company of London, V. 3, 669.
} 
terms and at extravagant length, appealed to English national pride in the pursuit of "this Noble Enterprise" of colonization, and promised perspective colonists 100 acres of land on the Virginia Company's behalf. Plainly, the Company had no intention of abandoning the project to which it had committed so many people and so many resources. ${ }^{76}$

Ultimately, Gleach's contention that Opechancanough's goal in launching a surprise attack on English settlements and plantations to contain the foreign interlopers seems more logical than the theory that his aim was to exterminate or expel the Tassantassas. Given the impossibility of storming fortified positions, Opechancanough may have given up the lands in which the Tassantassas concentrated their population as lost. As intimately familiar with his unwanted English neighbors as he would have become during the years that he acceded to English demands, Opechancanough almost certainly had some idea of the challenges involved in dismantling an entire colony and transporting settlers back to an England that held few prospects for them. It is possible that he was indifferent to what would become of the invaders, so long as they ceased to trouble his people, but he could not have been unaware that they would resist the idea of abandoning what for many settlers represented their only chance at prosperity. And while most narratives, both primary and secondary, depict Opechancanough as strictly a warrior while displaying Powhatan's acquisitive side, the war-leader was probably not indifferent to the value of European goods in a Native American trading network.

\footnotetext{
${ }^{76}$ Waterhouse, "A Declaration of the State of the Colony and Affaires in Virginia," in Kingsbury ed., The Records of the Virginia Company of London, V-3, 545-564, Public Record Office, London: List of Records No. 354 "Note of Arms in the Tower for Which the Virginia Company are Suitors," in Kingsbury ed., The Records of the Virginia Company of London, V. 3, 665, Treasurer and Council for Virginia, "Letter to Governor and Council in Virginia, August 1, 1622,"in Kingsbury ed., The Records of the Virginia Company of London, V. 3, 668-670.
} 
If Opechancanough had sought to confine the Tassantassas to a small cluster of settlements and discourage efforts to incorporate the region's Indians into their colony, then his success was fleeting. Wyatt and the Council in Virginia did indeed order the consolidation of the colony's surviving population, and English efforts at education and conversion of Native Americans certainly died with the first English casualty of the Uprising. But in the intervening months, Powhatans must have watched with growing apprehension as ships sailed into the Chesapeake Bay and up the James River to deposit more of England's surplus population on Virginia's shores. It must surely have occurred to Opechancanough that the fortified peninsula to which the Tassantassas had withdrawn would never support all of the new arrivals, and the Tassantassas therefore had no intention of remaining restricted to that peninsula.

Proclamations against such mundane offenses as drunkenness, swearing, taking of boats without permission, and stealing of oars indicate that by June, some semblance of normalcy had returned to colonial life as Wyatt and the Council awaited the Virginia Company's reply to their report on the Uprising. The next year, Wyatt would set a historical precedent for the modern commemoration of surprise attacks with an executive order to keep March 22 holy. Wyatt's call for a day of prayer and thanksgiving in consideration of "Gods most mercifull deliverance of so many in the Cuntrie of Virginia from the treachery of the Indian," held the unwritten, but easy to discern message that Englishmen on both sides of the Atlantic should never forget that perceived treachery. Nor would Opechancanough's surprise attack be forgiven, as aroused and reinforced 
settlers gathered their strength and armed themselves for military action calculated to make the Powhatans believe that the sky had indeed fallen. ${ }^{77}$

${ }^{77}$ Sir Francis Wyatt "Proclamations, June 21, 1622," in Kingsbury ed., The Records of the Virginia Company of London, V. 3, 658-659; Governor in Virginia "Order to Keep the 22d of March Holy, March 4, 1622/3," in Kingsbury ed., The Records of the Virginia Company of London, V. 4, 40; John Wooley and Gerhard Peters ed., "Presidential Proclamation 7462, National Day of Prayer and Remembrance for the Victims of the Terrorist Attacks on September 11, 2001," The American Presidency Project, 2014, accessed February 3, February, 2016, http://www.presidency.ucsb.edu/ws/index.php?pid=61759; "140 - Fireside Chat, Dec. 9, 1841," The American Presidency Project, 2014, accessed February 3, 2014. 


\section{CHAPTER III \\ SHORT-TERM CONSEQUENCES \\ English Rage Fuels English Policy}

The first rumblings of the outrage felt in England when news of the Uprising arrived on the Sea Flower in the summer of 1622 reached Virginia with the Company's reply to Wyatt and the Council. Although primarily concerned with chastising Wyatt and the Council, and dictating the colony's next course of action, the Virginia Company's officers managed passing references to the Powhatans, and perhaps to Native Americans in general as "men so contemptible," who practiced evil customs. In an unmistakable call for decisive military action, the Company concluded that Virginia's colonists could never again trust the goodwill of "so cursed a nation, ungratefull to all benefitte, and uncapable of all goodnesse," and at the very least should forcibly affect the removal of Native Americans from the vicinity of English settlements. It is very easy to view the Company's instructions to the Council in Virginia as a precedent for a practice that English settlers would follow as their mother country deposited more and more of its surplus population on North America's shores, and as an approach to Native American relations that remained in force well after England's North American colonies gained 
their independence and became the United States of America. ${ }^{78}$

Donne advocated continued missionary work in his sermon to the Company at St. Paul's, and John Martin, who had served as a member of the first Council in Virginia, submitted an essay to the Company in December, 1622, that argued for the subjugation, rather than the removal or extermination, of the Powhatans. Like Donne, Martin believed that the Virginia colony represented hope for the salvation of Native Americans, and their removal from the vicinity of Christians who could save them through conversion would doom their souls for eternity. However, Martin seemed to place more importance on the service the Powhatans did for the colony by killing wolves and bears that would otherwise pose a threat to the settlers' livestock. ${ }^{79}$

Voices like Donne's and Martin's seem to have been drowned out in a widespread outcry for revenge, with writers like Waterhouse and Brooke fanning the flames. Far from saving the colonists' cattle from predatory animals, the Powhatans were themselves rapacious beasts "more fell then Lyons and Dragons." Three months before Donne urged continued efforts to educate and convert Virginia's Native Americans, Purchas, the rector of St. Martin's parish in Ludgate, thundered from an open-air pulpit at St. Paul's Cross in London that Englishmen would soon wash their feet in the blood of "those native unnatuall Traytors". Virginia Company policymakers seemed to agree with Martin that Native Americans could make a valuable labor force in the development of Virginia. But where Martin, apparently a staunch adherent of the Company's recently

\footnotetext{
78 Treasurer and Council for Virginia, "Letter to Governor and Council in Virginia, August 1, 1622," in Kingsbury ed., The Records of the Virginia Company of London, V. 3, 666-672.

${ }^{79}$ John Martin. "The Manner Howe to Bringe the Indians into Subiection, December 15, 1622," in Kingsbury ed., The Records of the Virginia Company of London, V. 3, 704-706.
} 
abandoned policy of coexistence with and education of Native Americans, advocated the recruitment of willing Native American laborers, the Company's officers had little concern for the willingness of a potential Indian work force. In the beginning of an English experiment with Native American slave labor, the Company's treasurer and council advised Wyatt to spare young Powhatan prisoners of both sexes "whose bodies may, by labor and service become profitable." $\$ 0$

Along with ordering military action against the Powhatans and providing Wyatt with additional settlers and weapons to make that action a practical option, the Virginia Company also outlined methods by which the colonists could affect the forcible removal of Native Americans from the vicinity of English settlements and plantation. Not surprisingly, given the fact that an ocean separated Virginia from its supply lines, the Company recommended the seizure of Powhatan food stores and the destruction of Powhatan cornfields. Additionally, the Company recommended the establishment of a standing militia in Virginia to intercept Powhatan hunting parties, burn their towns, destroy their boats, and generally deny them "whatsoever may yeeld them succor or relief." The various Indians who had warned colonists of Opechancanough's designs, the Treasurer and Council opined, were due a "good respect and recompence," in the form of continued indoctrination in English ways "whereby they may be made capable of further

\footnotetext{
${ }^{80}$ Waterhouse, "A Declaration of the State of the Colony and Affaires in Virginia," in Kingsbury ed., The Records of the Virginia Company of London, V. 3, 551; Treasurer and Council for Virginia, "Letter to Governor and Council in Virginia August 1, 1622," in Kingsbury ed., The Records of the Virginia Company of London, V. 3, 672; Purchas, The kings tovvre and triumphant arch of London. A sermon preached at Pauls Crosse, August. 5. 1622. (London: W. Stansby, 1623), 100.
} 
benefitte and favor.” In short, their demonstrated subservience to English colonists had made them worthy to remain in the vicinity of English settlements, so long as they did so on English terms. ${ }^{81}$

While the Uprising did not impact Wyatt's determination to maintain an English presence in Virginia, it brought about a dramatic change in his attitude toward his Native American neighbors. A leading advocate of peaceful coexistence with the region's Indians before Opechancanough's attacks, he concluded shortly after the Uprising that the expulsion of the region's Indians was Virginia's first priority. Settlers would be infinitely better with no Indians among them, Wyatt wrote, than to have peaceful Native American neighbors whom he declared to be thorns in the colony's side at the best of times. Alden T. Vaughan viewed Wyatt's statement as a forecast of English posture toward Native Americans for the remainder of the seventeenth century: one of unrelenting enmity and almost complete separation. ${ }^{82}$

The Virginia Company seems to have wasted little time disseminating proVirginia, anti-Powhatan propaganda to the English public. Just over a month after the Sea Flower arrived in London bearing news of the Uprising, the Company had published Waterhouse's report as a broadsheet. Waterhouse opened "A Declaration of the State of Affaires in Virginia," by praising the region's natural beauty and abundance at great length in an obvious effort to tempt prospective settlers. His description of the richness of

\footnotetext{
${ }^{81}$ Treasurer and Council for Virginia, "Letter to Governor and Council in Virginia August 1, 1622," in Kingsbury ed., The Records of the Virginia Company of London, V. 3, 672-673.

${ }^{82}$ Vaughan, “'Expulsion of the Salvages': English Policy and the Virginia Massacre of 1622," 58.
} 
Virginia's soil would have been especially alluring in a small, overpopulated island nation where land, the measure of wealth in seventeenth-century Europe, was in short supply.

Having piqued the greed of potential colonists, he then fed their anger with a lurid depiction of the Uprising, during which the Powhatans, not content with merely killing their English victims, "fell after againe upon the dead, making as well as they could a fresh murder, defacing, dragging, and mangling the dead carkasses into many pieces, and carrying some parts away in derision, with base and brutish triumph." It is somewhat surprising that Waterhouse, in his graphic allegations of Native American savagery, did not speculate that the parts of slain colonists that the Powhatans reportedly carried back to their towns were destined for communal cooking pots. Certainly, he had a clear opportunity to accuse Virginia's Native American enemies of what may be one of mankind's greatest taboos, and allegations of cannibalism would have fit in with his attempt to make the Powhatans seem as abhorrent as possible to his English readers. ${ }^{83}$

"A Declaration of the State of the Colony and Affaires in Virginia," derived its considerable influence from Waterhouse's contention that the 1622 Uprising was actually advantageous to the colony in the long run. First, he declared, the Powhatans had revealed themselves as enemies of God through their treacherous violence against Christians. Because they were brutal and duplicitous enemies of God, Christian colonists were free to act against them, whereas their hands had previously been "tied

\footnotetext{
${ }^{83}$ Waterhouse, "A Declaration of the State of the Colony and Affaires in Virginia," in Kingsbury ed., The Records of the Virginia Company of London, V. 3, 541-551.
} 
with gentlenesse and fair usage." By turning their laborious mattocks into victorious swords, Waterhouse wrote, colonists in Virginia could claim the region's best farmland, while they had previously subsisted on what he saw as land that the Indians did not want. Additionally, the deer and other game animals would increase when the Indians who hunted them had been driven out of the region, as would English livestock. Waterhouse's view of the Powhatans as a threat to English livestock was diametrically opposed to Martin's portrayal of the indigenous Native Americans of defenders of that livestock through their hunting of predators. It is ironic that Waterhouse expressed concern for the game animals whose natural habitat English colonists were actively levelling for farmland. ${ }^{84}$

Conquering the Powhatans, Waterhouse asserted, would be easier than "civilizing" them, because they were "scattered in small companies, which are helps to Victorie, but are hindrances to Civilitie." Like Martin, Waterhouse recognized the potential value of Native American labor in Virginia, and because of their demonstrated hostility, the Powhatans could "most justly be compelled to servitude and drudgery." Prophetically, Waterhouse stated that Opechancanough's attacks had taught Virginia's colonists and their Virginia Company backers that "he who trusts not is not deceived." It is reasonable to suggest that the Euro-American distrust of Native Americans and the determined Euro-American displacement of Native Americans were rooted in Waterhouse's 1622 assessment of Anglo-Indian affairs in Virginia. ${ }^{85}$

\footnotetext{
${ }^{84}$ Waterhouse, "A Declaration of the State of the Colony and Affaires in Virginia," in Kingsbury ed., The Records of the Virginia Company of London, V. 3, 556-557.

${ }^{85}$ Waterhouse, "A Declaration of the State of the Colony and Affaires in Virginia," in Kingsbury ed., The Records of the Virginia Company of London, V. 3, 556-559.
} 
Waterhouse was quite explicit in the ways by which Virginia's colonists could conquer and expel the Powhatans. Like the Treasurer and Council of the Virginia Company, Waterhouse proposed raids on Powhatan towns, destruction of Powhatan goods, harvesting Powhatan fields at gunpoint, and surprise attacks on Powhatan hunting and foraging parties. What particularly stands out about Waterhouse's report was his persistent dehumanization of Native Americans, advocating the pursuit of them with horses, bloodhounds, and mastiffs, using essentially the same methods they would have employed to eradicate wolves and foxes in Europe. ${ }^{86}$

Citing the efforts of a rival European power in the early competition for preeminence in North America, Waterhouse related the success of Spanish colonizers in using Native American quarrels and rivalries to their own advantage in their sixteenth century conquests of Mexico and Peru. Forty years earlier, Richard Hakluyt had written in gruesome detail about the cruelty of Spanish conquistadores on Native Americans, describing how they "ripped their bellies and cut them in peces as if they had bene openinge of lambes shutt up in their folde," and trained hounds to "teare them in peces at the first view." Such atrocities, Hakluyt wrote, had made Spain's agents of colonization odious to the people over which they ruled. In a 1609 Virginia Company promotional tract, London Alderman and prominent Company investor Robert Johnson boasted that England would gain a foothold in the New World not through use of swords and muskets, as the Spanish had established a base in the West Indies, but through "faire and loving meanes fitting to our English natures." Given the repudiation of Spanish methods that

\footnotetext{
${ }^{86}$ Waterhouse, "A Declaration of the State of the Colony and Affaires in Virginia," in Kingsbury ed., The Records of the Virginia Company of London, V. 3, 557-558.
} 
earlier advocates of English colonization professed, Waterhouse's assertion that Spain's example was one for English colonists to emulate represented a dramatic change in attitude. $^{87}$

Making divisions among the region's various Native American groups would be easy because many of those groups already hated the Powhatans "that have beene likely as false and perfidious to them, as unto us of late." Undoubtedly, the conquests of the Powhatans before the arrival of the English had generated some resentment on the part of the peoples they had conquered, But the divide-and-conquer tactics that Waterhouse prescribed probably met with limited success, as armed settlers often did not stop to distinguish friend from foe before firing on Native Americans after the 1622 Uprising. ${ }^{88}$

Because Waterhouse's diatribe appeared in a Virginia Company publication, the views he expressed presumably carried the Company's imprimatur. Because the Company appointed the members of Virginia's governing body during its management of the colony, Waterhouse's recommendations therefore can be said to have carried the weight of official policy.

Wyatt appears to have anticipated the Virginia Company's instructions to let the Powhatans have "warre without peace or truce." Before receiving the Company's instructions, the Governor in Virginia issued a commission to his predecessor, Sir George Yeardley, instructing him to recruit militia, travel to the York River and around the

\footnotetext{
${ }^{87}$ Waterhouse, "A Declaration of the State of the Colony and Affaires in Virginia," in Kingsbury ed., The Records of the Virginia Company of London, V. 3, 558; Hakluyt, A Discourse Concerning Western Planting, 71, 75-77; Robert Johnson, Nova Brittania. Offering Most Excellent Fruits by Planting in Virginia. Exciting All Such as be Well Affected to Further the Same, (New York: J. Sabin, 1867), 14.

${ }^{88}$ Waterhouse, "A Declaration of the State of the Colony and Affaires in Virginia," in Kingsbury ed., The Records of the Virginia Company of London, V. 3, 558.
} 
Chesapeake Bay, and "make war, kill, spoile, or take by force or otherwise whatsoever boote of Corne, or anything else he can attaine unto, from any the Salvadges or enemies." After the meticulously planned and coordinated March 22 attacks, Opechancanough and the Powhatans had settled into the time-honored siege tactic of denying the countryside and its resources to the Tassantassas. Wyatt, having reinforced the colony's ranks, regrouped in fortified positions, and replenished Virginia's armory, was clearly planning to break out of the settlements to claim the countryside and its resources. ${ }^{89}$

The first few years of the Second Anglo-Powhatan War were years of depredation for all participants. At the outset, the Powhatans had several distinct advantages over their European opponents. Unless they were actually under attack, they enjoyed freedom of movement that the entrenched English lacked. Both sides raided the other's food supplies, creating a shortage of grain all around, but the Powhatans, better knowing the land, knew how to subsist on wild plants including tuckahoe, a starchy root that grew in the swamps. There can be little doubt that mutual destruction of cornfields caused more suffering among the English, who lacked such intimate knowledge of the forests and marshes, than it did among the Powhatans. Bottled up in their settlements, between 500 and 600 colonists would die of disease and starvation. Wyatt's commission to Hamor in October, 1622, stating the necessity that "by war or trade, Corne be procured from the

\footnotetext{
${ }^{89}$ Treasurer and Council for Virginia, "Letter to Governor and Council in Virginia August 1, 1622," in Kingsbury ed., The Records of the Virginia Company of London, V. 3, 672; Governor in Virginia, "A Commission to Sir George Yeardley September 10, 1622,"in Kingsbury ed., The Records of the Virginia Company of London, V. 3, 678-679; Governor of Virginia, "A Commission to Captain Ralph Hamor, October 23, 1622," in Kingsbury ed., The Records of the Virginia Company of London, V. 3, 697.
} 
Indians," showed that obtaining food was the colony's first priority. In the next two months, Wyatt issued similar commissions to Captains William Eden, Isaac Maddison, William Tucker, and Robert Bennett, further demonstrating the urgency he felt in feeding the colony. Maddison's trading expedition to the neutral Patawomecks was an unmitigated disaster. His suspicions aroused by a guide's rumor that the Patawomecks were plotting with Opechancanough to attack his party, Maddison ordered an assault on a Patawomeck town, killing between 30 and 40 Indians. The Accomacs of the Eastern Shore seem to have been the only Native American group to maintain any sort of cordial relations with the English. Hamor's expeditions to the Accomacs in the summer of 1622 yielded the colony eight bushels of maize, and Tucker was able to procure another 12 bushels from the same source. Wyatt and the Council were obviously not going to feed the colony through trade, but raids on Indian food supplies yielded thousands of bushels of corn. ${ }^{90}$

The Virginia Company's advice to Wyatt after the Uprising included an injunction to "roote out from being any longer a people" the Powhatans who had so violently rejected English culture and faith and were therefore unworthy to live in proximity to English settlements. Waterhouse wrote admiringly of the efforts of sixteenth century Spanish colonists in the West Indies who, through 40 years of warfare, denial of food sources, and exacerbation of local quarrels to their own advantage, reduced the Indian population there from more than a million to about 500. Taken together, the two

\footnotetext{
${ }^{90}$ Rountree, Pocahontas, Powhatan, Opechancanough, 172; Smith, The Generall Historie of Virginia, New England \& The Summer Isles, 304-305; Virginia General Assembly, "A Court held the $7^{\text {th }}$ of March 1623," in Minutes of the Council and General Court of Colonial Virginia: 1622-1632, 1670-1676: With Notes and Excerpts from Original Records and General Court Records, Into 1683, Now Lost, H. R. McIlwaine ed., (Richmond, VA: Virginia State Library, 1924), 11.
} 
documents present a fairly strong case that the Company was advocating extermination of any Indians who refused to vacate the land around English settlements or plantations

\section{The Second Anglo-Powhatan War}

An incident that occurred in the spring of 1623 demonstrates how vindictive Wyatt, formerly a leading proponent of English coexistence with the region's Indians, had become after the Uprising. Opechancanough had sent emissaries to Martin's Hundred to propose a truce that would allow both sides to plant crops, and to carry an offer to return the surviving English prisoners taken the previous year. One of Opechancanough's emissaries was the same Chanco whom many historical narratives credit with saving Jamestown from the ravages of the Uprising with his timely warning to Richard Pace. The other, a weroance named Comahum, recognized as an active participant in the surprise attacks of the Uprising, was put in chains and both messengers were escorted to Jamestown. Wyatt received the embassy, and pretended acceptance of Opechancanough's terms. However, he plainly saw that by giving the Powhatans a chance to plant their corn, he would know where and when to reap the Tsenacomoco harvest for Virginia's storehouses. In spite of Opechancanough's promise to release the prisoners from Martin's Hundred before truce negotiations opened, only one woman, a Mrs. Boyse, was initially released and escorted back to Jamestown. The difficulty in releasing the others seems to have been largely a result of high-handed behavior on the part of English interpreter Robert Poole, because Boyse carried a request that Wyatt recall him and send another 
interpreter with assurances that the truce was genuine. Poole's unnamed replacement duly arrived at Pamunkey with a stock of glass beads to pay for the release of the remaining prisoners. Wyatt agreed to a meeting and dispatched Tucker, escorted by a dozen armed militiamen, to negotiate on the colony's behalf and bring the remaining English prisoners home. ${ }^{91}$

Wyatt and the Council provided Tucker's party with casks of wine, with which they could invite their counterparts at Pamunkey to toast the success of the peace negotiations. The wine meant for the Powhatans, however, was poisoned. Tucker and his party made a great show of drinking first, filling their mugs with untainted wine from another, hidden cask. An estimated 200 Indians succumbed to either the poison or the musket balls that Tucker's party fired into them. Opechancanough was said to have been both poisoned and shot, and Tucker had apparently assured the Council that the warleader had died from one or the other "it beinge impossible for him to escape." 92

Opechancanough did not die, but his name does not appear in written records for several years, strongly suggesting that either the poison or the shot-wounds had incapacitated him during that time. The use of mass poisoning as a military tactic suggests that Wyatt and the Council had taken the dehumanizing rhetoric of Waterhouse and Brooke to heart. Tucker's method was evocative of a modern homeowner setting out poisoned bait to eliminate rats or cockroaches. Tucker's tactic seems to have been more than even the officers of the Virginia Company, who had called for a perpetual war

\footnotetext{
${ }^{91}$ Rountree, Pocahontas, Powhatan, Opechancanough, 173-174; Kingsbury ed., The Records of the Virginia Company of London, V. 4, 98-99.

${ }^{92}$ Rountree, Pocahontas, Powhatan, Opechancanough,174-175; Kingsbury ed., The Records of the Virginia Company of London, V. 4, 221, 270-271.
} 
against the Powhatans, could readily stomach. The Company's August, 1623 letter to Wyatt and the Council warmly approved their resolution to utterly drive away Virginia's treacherous enemies, but mildly rebuked their particular method, writing that they were "to worthie to use any false dealings, and we desire that your proceedinge may be so faire as may not only be free from the fault, but any just ground of suspicion." The admonishment was mild in comparison to the reprimand the Company issued in the aftermath of the Uprising. Concern for its own public image, rather than horror at the treacherous method by which English colonists had slaughtered their hosts at Pamunkey, is most likely have been the Company's motivation in issuing a reproach of any kind. The mass poisoning incident was significant not only because of the number of Powhatans who died, or merely because it deprived them of Opechancanough's experience at fighting the Tassantassas, but because Tucker's party had an opportunity to scout the land along the Pamunkey River and discover where the Powhatans were residing and growing their corn. Because of this knowledge, English raids on the Powhatans in the next year would cause more damage to their towns and pilfer more food than they had prior to the aborted truce talks at Pamunkey. ${ }^{93}$

The English strategy for the first two years of the Second Anglo-Powhatan War was largely one of separation from Native Americans, because the colonists lacked the manpower to carry out an extermination program during that time. The outbreak of hostilities and the new English policy of creating distance between themselves and Native

\footnotetext{
${ }^{93}$ Rountree, Pocahontas, Powhatan, Opechancanough, 174-175; Robert Bennett. "A Letter to Edward Bennet, June 9, 1623," in Kingsbury ed., The Records of the Virginia Company of London, V. 4, 221, Governor in Virginia. "Proclamation, August 31, 1623" in Kingsbury ed., The Records of the Virginia Company of London, V.4, 70-271; Virginia General Assembly, "A Preparative Court held on Monday in the Afternoone the 17th OF November, 1622," in Kingsbury ed., The Records of the Virginia Company of London, V. 2, 482; Horn, A Land as God Made It, 285.
} 
American communities was probably beneficial for the Powhatans in one regard.

Extremely limited contact with the Tassantassas would have at least partially protected the Powhatans from the epidemics that arrived in Virginia with new settlers and decimated English settlements. ${ }^{94}$

On the English side lay two significant advantages: military technology and replaceable personnel. Military technology was certainly a critical factor in the only pitched battle of the Second Anglo-Powhatan War. In the fall of 1624, Wyatt personally led a force of militia to Pamunkey, where he claimed to have defeated 800 bowmen under Opitchapam in a two-day battle during which Wyatt reported that his troops had cut down enough corn to feed 4,000 men for a year. Only a shortage of gunpowder prevented Wyatt from launching more such attacks. Opitchapam appears to have had limited experience at fighting the Tassantassas, because it is doubtful that Opechancanough would have faced armored, musket-wielding Englishmen in a pitched battle. ${ }^{95}$

Opechancanough would certainly have been aware of how decisive European firearms and cannons would be, having demonstrated reluctance to assault fortified settlements in the teeth of English artillery. Just as certainly, the Powhatans would have captured muskets and powder bags from many of their English victims in the Uprising. Waterhouse provided an anecdote in which Opechancanough, having no idea of the process of making gunpowder, assumed it came from a plant and had gunpowder sewn

\footnotetext{
${ }^{94}$ Treasurer and Council for Virginia, "Letter to Governor and Council in Virginia, August 1, 1622," in Kingsbury ed., The Records of the Virginia Company of London, V. 3, 672; Waterhouse, "A Declaration of the State of the Colony and Affaires in Virginia," in Kingsbury ed., The Records of the Virginia Company of London, V. 3, 561; Cave, Lethal Encounters, 128; Rountree, Pocahontas, Powhatan, Opechancanough, 172.

95 Council in Virginia. "Letter to the Earl of Southampton and the Council and Company of Virginia, December 2, 1624," in Kingsbury ed., The Records of the Virginia Company of London, V. 4, 507-508.
} 
into the ground as if it were seed grain. In this instance, Waterhouse appears to have been lampooning Opechancanough and his followers as absurd and untutored. Elsewhere in "A Declaration of the State of Affaires in Virginia," Waterhouse ridiculed Native Americans as "so naked a cowardly a people," who fled from their own women "as so many Hares; much faster than from their tormenting Devill." Having satirized his people as timorous and henpecked, Waterhouse had no reason to refrain from drawing a verbal caricature as Opechancanough himself as abysmally ignorant. His report, after all, not only announced changing English policy, but was a major part of the Virginia Company's propaganda campaign. ${ }^{96}$

English Virginia's crucial asset in the war with Powhatan-dominated Tsenacomoco, ultimately, was what must have seemed to the Powhatans to be an unlimited supply of replaceable personnel. One of the Virginia Company's first responses to Wyatt's report of the Uprising was to recruit 400 settlers with a promise of many more. During the remainder of 1622 and throughout 1623, the Company shipped hundreds of settlers to a colony that lacked adequate food and shelter for them. The close quarters of shipboard life facilitated the spread of disease during the voyage, and many prospective settlers died at sea. Wyatt's own wife, crossing from England in 1623, appears to have escaped the unnamed epidemic that decimated the crew and passengers of the ship on which she traveled, surviving to note with horror that she saw little else during the voyage but the dead being thrown overboard. Others would die on arrival from starvation, disease, and Powhatan hostility. But in the coming years, more ships from

\footnotetext{
96 Waterhouse, "A Declaration of the State of the Colony and Affaires in Virginia," in Kingsbury ed., The Records of the Virginia Company of London, V.3, 556.
} 
England arrived in Virginia, carrying more colonists. In spite of a death toll that prompted James I to order an investigation of the Company's management of Virginia late in 1623, the colony's population had increased slightly from 843 after the Uprising to 1,275 by the beginning of 1624 . In the following decade, that number nearly quadrupled to 4,914. In a war of attrition such as the one into which Virginia's colonists had settled against the Powhatans, the English, who could absorb casualties and replace losses, held a significant edge. That advantage would allow them to break out of the settlements and put their new policy toward Native Americans into practice. ${ }^{97}$

The war degenerated into incessant reciprocal raids after Wyatt's defeat of Opitchapam at Pamunkey. The rout of 800 elite warriors who made up the backbone of Powhatan fighting forces, the consequential loss of crucial food supplies just before winter, and the infirmity of their greatest war-captain after the mass poisoning incident seem to have demoralized the Powhatans, because by the winter of 1625 , Wyatt reported to the royal Commissioners for Virginia that Opitchapam had sued for peace. As he had done in 1623 , Wyatt planned to make a show of amenability to peace because the Powhatans would then plant great quantities of corn in places known to the English. His speculation that the supplies of ammunition and gunpowder the Commissioners had promised would give the colony "fayre opportunity to revenge theire former Trecheries," if they arrived in Virginia in time show conclusively how little Wyatt was interested in ending hostilities with the Powhatans. ${ }^{98}$

\footnotetext{
${ }^{97}$ Vaughan, "'Expulsion of the Salvages': English Policy and the Virginia Massacre of 1622," 80; 13; Ronald Seavoy, An Economic History of the United States: From 1607 to the Present, (New York: Taylor \& Francis Group, 2006), 13; Warren M. Billings, The Old Dominion in the Seventeenth Century: A Documentary History of Virginia, (Chapel Hill, N.C.: University of North Carolina Press, 1975), 118. ${ }^{98}$ Governor and Council in Virginia, "A Letter to the Commissioners for Virginia, January 4, 1625/6," in Kingsbury ed., The Records of the Virginia Company of London, V. 4, 569.
} 
Opechancanough appears to have remained infirm throughout 1628, because Opitchapam continued to direct the Powhatan war effort. The Powhatans, who had shown a propensity for killing the English men they had captured while adopting the women captured at Martin's Hundred, had spared the English male prisoners taken through the course of 1628. Opitchapam allowed one of his English prisoners to send a message to Jamestown. Opitchapam's gesture of sparing and eventually repatriating male prisoners appears to have sufficiently placated Acting Governor Francis West that he entered into negotiations that led to another truce. The provisions of the proposed treaty appear to have focused on continued separation between Virginia's colonists and Tsenacomoco's Indians, with the Powhatans agreeing to stay out of English territory and refrain from killing English livestock. West, however, was no more desirous of a lasting peace with the Powhatans than Wyatt had been. Few English writers of the period appear to have been able to refrain from applying the word "treacherous" in reference to Native Americans or the word "treachery" to describe Native American actions. West was no exception, and was quick to point out that he had agreed to a truce with the Powhatans in the spring of 1628 "not to make any peace or dishonorable treaty with them," but to lull them into the same sense of complacency that Opechancanough had cultivated among the colonists six years earlier. ${ }^{99}$

The truce seems to have lasted only a few months before West found an excuse to break it. In January, 1629 he reported that the Powhatans "have been extremely false and

\footnotetext{
${ }^{99}$ Rountree, Pocahontas, Powhatan, Opechancanough, 177-178; Governor and Council in Virginia, "A Cort at James Citty the 24th Aprill 1628," in McIlwaine ed., Minutes of the Council and General Court of Colonial Virginia, 172; Governor and Council in Virginia, "A Cort at James Citty the last day of January 1628," in Mcllwaine ed., Minutes of the Council and General Court of Colonial Virginia, 184; Cave, Lethal Encounters, 129.
} 
altogether neglected the Condicons of the treaty and offered some Injuries in dyvers of our plantacons." After serious deliberation, the Governor and Council in Virginia concluded that the colony's safest course was to "utterly proclayme and maintayne enmity and warres with all the Indians of these partes," in order to prevent a second Uprising. ${ }^{100}$

For the next three years, the two sides settled into a familiar pattern of reciprocal raiding. However, the English were able to bring its most important resource replaceable personnel - increasingly to bear. The Virginia colony continued to grow and Tsenacomoco continued to shrink as more settlers poured into the region intent on making their fortunes raising tobacco. English militia began raiding towns that had previously been spared the devastation of years of warfare. A plan for settlers to occupy the town that had been the seat of the Chiskiacks in the spring of 1629 shows English awareness that Opechcancanough remained alive, and quite possibly more inimical than ever after a six-year convalescence from English treachery at Pamunkey. An advantage that newly-installed governor Sir John Harvey and the Council for Virginia saw in settling the town was its proximity to important Powhatan towns on the Pamunkey, which would enable the colonists to "face their greatest enemy Appechankeno and disable the savages" the following spring. ${ }^{101}$

When the two sides eventually made peace in 1632 , the treaty appears to have been at least partly the result of food shortages on both sides. The Council for Virginia

\footnotetext{
${ }^{100}$ Governor and Council in Virginia “A Cort at James Citty the last day of January 1628," in Mcllwaine ed., Minutes of the Council and General Court of Colonial Virginia, 184.

${ }^{101}$ Sir John Harvey, "Colonial Paper 93, May 29, 1630," in Calendar of State Papers, Colonial Series, 1574-1660, America and West Indies, V. 5, W. Noel Sainsbury ed., (London: Longman, Green, Longman, \& Roberts, 1860), 116.
} 
briefly noted that a drought that summer had caused a great scarcity of corn. By June, the Chickahominies, undoubtedly feeling the effects of the drought, had broken ranks with Opechancanough and sued for a separate peace with the Tassantassas. Three months later, the Governor and Council reported that Virginia was at peace with the Chickahominies and the Pamunkeys, but warned settlers against trusting them. Clearly, the events of March 22, 1622 had been neither forgotten nor forgiven. ${ }^{102}$

${ }^{102}$ Governor and Council in Virginia, "In a Roll No. 10," in Mcllwaine ed. Minutes of the Council and General Court of Colonial Virginia, 480; Governor and Council in Virginia, "Book No. 43," in McIlwaine ed., Minutes of the Council and General Court of Colonial Virginia, 484; Rountree, Pocahontas, Powhatan, Opechancanough, 178. 


\section{CHAPTER IV}

\section{THE FALL OF THE VIRGINIA COMPANY}

Perhaps the most significant English casualty of the Second Anglo-Powhatan War was the Virginia Company of London, the joint-stock company in which both Edward Waterhouse and Christopher Brooke had invested. It is probably not a coincidence that two of the most strident English advocates of all-out war with the Powhatans had made significant investments in the Virginia Company of London. Edward Waterhouse was not only a Company employee, but he had purchased 25 pounds worth of Company stock: an outlay equivalent to several thousand dollars in modern currency. Christopher Brooke's investment doubled Waterhouse's. The loss of his investments are unlikely to have bankrupted Waterhouse, the nephew and heir of a former Chancellor of the Exchequer of Ireland. Nor would Brooke's loss of 50 pounds have consigned the prosperous lawyer and politician to a life of poverty. But it is easy to imagine Brooke grieving for his 50 pounds at the same time he lamented English casualties in his poem. It is similarly sensible to postulate that Waterhouse's vitriol against Native Americans was at least partially a reaction to Opechancanough's attacks on his personal interests. ${ }^{103}$

\footnotetext{
${ }^{103}$ Treasurer and Council for Virginia, "A Complete List in Alphabetical Order of the "Adventurers to Virginia,' with the Several Amounts of their Holding," in Kingsbury ed., The Records of the Virginia Company of London, V. 3, 80-83; Eric Nye "Pounds Sterling to Dollars: Historical Conversion of Currency," University of Wyoming, accessed January 19, 2016, http://www.uwyo.edu/numimage/currency.htm; "Waterhouse, Edward," in The Dictionary of National Biography, V. 49, Sir Sidney Lee ed., (London: Smith, Elder \& Co, 1899), 442-444, "Brooke, Christopher" in Lee ed., The Dictionary of National Biography, V. 6, 419.
} 
When King James I granted The Virginia Company of London a charter in 1606 that assigned land rights in Virginia to colonists traveling there, he clearly intended to monitor the project closely. The Council for Virginia, the colony's governing body, was to be comprised entirely of Company investors. However, the king reserved for himself the right to select Council members from the Company's ranks. Although the charter's sole stated purpose for establishing colonies in North America was the propagation of Christianity among people who "as yet live in Darkness and miserable Ignorance of the true Knowledge and Worship of God," James I could not have been insensible of the national importance of the Company's endeavor. Trade with the far east had been an objective for English merchants since the mid-sixteenth century, and several efforts had already been made to find a passage to China around or through the North American continent. Perhaps the key to a shorter route to the Orient than the Cape of Good Hope that was popular with Portuguese and English traders lay somewhere in the waterways that emptied into Chesapeake Bay. Additionally, Spanish colonization endeavors in the Americas had resulted in the discovery and exploitation of precious metals that would finance Spain's emergence as an imperial power that at its height controlled territories in Asia, the Americas, Europe and Africa. It would not have been difficult for the king to speculate about the national wealth that a successful colonial venture could bring, or the international prestige that new national wealth could convey. James I is likely to have seen that by allowing Virginia adventurers some measure of self-government, he could enjoy the benefits of a successful enterprise without incurring the inevitable expense of maintaining a colony. On the other hand, he clearly recognized that the colony's success 
was very much in his own interest, and could well have been arrogant enough to assume that the Virginia project could succeed only under his close supervision. ${ }^{104}$

The second charter, which James I approved in 1609, granted the Virginia Company more autonomy than the first, allowing its members to nominate, elect, and replace its own officers. But the king still seemed eager to maintain his close scrutiny of colonial affairs, requiring each new member of the Council in Virginia to "take his Oath of a Counsellor to Us, our Heirs and Successors, for the said Company of Adventurers and Colony in Virginia." A third charter, granted to the Virginia Company in 1612, confirmed the Company's right to appoint a Council for Virginia from among its membership to advise the king on colonial affairs. ${ }^{105}$

Since its formation in 1606, the Virginia Company of London had been divided into two factions: The Court Party and the Virginia Party. The Court Party, under the leadership of Sir Thomas Smythe, who for 10 years served as Treasurer, the Company's presiding official, favored a heavy-handed approach to the colony's governance. Colonists, in the eyes of Smythe and the Court Party, were employees of the Virginia Company of London, existed so that the Company could make a profit, and should have no voice in the control of colonial affairs. Virginia Party leaders like the Earl of Southampton, Sir Edwin Sandys, and Nicholas Ferrar, favored greater political independence for settlers and believed that the Court Party's restrictive policies had not

\footnotetext{
${ }^{104}$ King James I, “The First Charter of Virginia; April 10, 1606,” in The Federal and State Constitutions, Colonial Charters, and Other Organic Laws of the States, Territories, and Colonies Now or Heretofore Forming the United States of America, V. 7, Francis Newton Thorpe ed., (Washington, D.C.: Government Printing Office, 1909), 3783-3789; Wesley F. Craven, The Virginia Company of London, 1606-1624, (Baltimore, MD: Genealogical Publishing Co., Inc., 2004), 9-10.

${ }^{105}$ King James I, "The Second Charter of Virginia; May 23, 1609," in Thorpe ed., The Federal and State Constitutions, V. 7, 3797; King James I, "The Third Charter of Virginia, March 12, 1612," in Thorpe ed., The Federal and State Constitutions, V. 7, 3805-3806.
} 
only retarded English emigration to the New World, but had begun to drive many settlers back to England. The appointment of Virginia Company Treasurer and Court Party leader Sir Thomas Smythe's kinsman, Samuel Argall, as Virginia's governor in 1617 ultimately led to the end of Court Party dominance within the Company, because Argall proved a highly unpopular figure. Reports from Virginia filtered back to the Company that accused Argall of seizing public warehouses, appropriating the tobacco and grain in them for his own use, forcing indentured laborers to work for him rather than for the colony at large, and holding laborers in bondage after their terms of indenture had expired. The Company recalled Argall in 1618, and the next year, Sir Edwin Sandys replaced Smythe as Treasurer, largely on the strength of reports on Argall's misconduct. One of the Company's first moves under Virginia Party leadership was to accord Virginians the right of local self-government through a General Assembly that convened at Jamestown in the summer of $1619 . .^{106}$

The ascension of Sandys to the Virginia Company's top executive position was not calculated to please King James I. A notoriously autocratic ruler, James told Parliament in 1610 that kings were God's lieutenants on earth, and argued that "to dispute what God may do is blasphemy ... so is it sedition in subjects to dispute what a king may do in the height of his powers." ${ }^{\prime 107}$ It is not surprising that a monarch with such an exalted sense of his own position preferred the close supervision of colonial affairs

\footnotetext{
106 W.R. Garrett, "The Father of Representative Government in America," American Historical Magazine, V. 1, No. 1 (January, 1896), 7; Julian Alvin Carroll Chandler, Makers of Virginia History, (New York, Atlanta, Boston, Dallas, Chicago: Silver, Burdett and Company, 1904), 51; John Pory, "A Reporte of the manner of proceeding in the general assembly Convented at James City, July 30, 31, August 2, 3, 4, 1619," in Kingsbury ed., The Records of the Virginia Company of London, V. 3, 153.

${ }^{107}$ King James I, "Speech of James I before Parliament, 21 March, 1610, "in Select Statutes and Other Constitutional Documents Illustrative of the Reigns of Elizabeth and James I, Third Edition, G.W. Prothero, ed., (London, Edinburgh, New York and Toronto: Oxford at the Clarendon Press, 1906), 294.
} 
that Court Party leaders advocated to the relative self-government that the Virginia Party offered to settlers. Adding to the king's displeasure with the Company was Sandys' election as treasurer. Sandys, who had served for three decades in the House of Commons, was an outspoken critic of James' rule and a political ally of other members of Parliament who opposed his high-handed approach to governing. James I clearly saw Sandys as a political enemy, and when the Virginia Company was prepared to reelect him as Treasurer in 1620, the king sent representatives to the meeting to command the members to select someone else. According to some reports, James I attended the meeting in person and shrieked at the Company's investors to "Elect the devil, if you will, but not Sir Edwin Sandys!" Sandys, hoping to preserve peace, withdrew his name as a candidate for Treasurer, but with the election of the Earl of Southampton and the appointment of Ferrar as deputy treasurer, the Virginia Party retained its control of the Company. It was probably at this point that James I decided to revoke the Virginia Company's charter and was merely seeking an excuse to do so. The 1622 Uprising, and the Company's reaction to the crisis, provided him with the pretext he craved. ${ }^{108}$

James I seems to have had a particular stake in the economic diversification project that the Virginia Company undertook when Sandys assumed leadership as Treasurer in 1619. Thanks to John Rolfe's efforts to cultivate a strain of West Indian tobacco that was milder and more to European tastes than its harsh-tasting native counterpart, Virginia had been exporting a cash crop since 1612. However, the colony's dependence on tobacco as an export crop would have incurred royal displeasure, because

\footnotetext{
108 Chandler, Makers of Virginia History, 64; Garrett, "The Father of Representative Government in America," American Historical Magazine, V. 1, No. 1 (January, 1896), 8.
} 
James I was vehement in his disdain for smoking. In his 1604 treatise "A Counterblaste to Tobacco," one of the first anti-tobacco publications in Western history, the king expressed his scorn for smoking as a "vile, barbarous custome," and Native Americans who introduced the habit to Europeans as "beastly Indians, slaves to the Spaniards, refuse to the world, and as yet aliens from the holy Covenant of God." Why, he mockingly demanded, should English smokers stop at adopting one Native American practice, when they could further imitate Indians by dressing scantily, preferring trinkets like mirrors and feathers to gold and jewels, and renouncing Christianity? ${ }^{109}$

Sandys is likely to have been aware of the king's distaste for smoking, and could well have felt considerable pressure to develop new commodities in Virginia that would alleviate the colony's dependence on tobacco as a cash crop. In a 1619 inventory of the ships, colonists, and provisions sent to Virginia during the year, Sandys listed the commodities that he hoped settlers would focus their energies on developing. He directed 150 new settlers who had been recruited specifically for the purpose to set up three iron works, "proofe having been made of the extraordinary goodnesse of that Iron." It is plain that Sandys also saw Virginia as a treasure trove of raw materials for shipbuilding, because he directed the Council in Virginia to oversee the production of cordage, tar, pitch, and timber. Additionally, he thought Virginia's climate would be suitable for the cultivation of mulberry trees and vines, which would in time produce silk and wine, which would make valuable trading commodities. The ambitious scope of Sandys' economic diversification project shows the Virginia Company's commitment to the

\footnotetext{
${ }^{109}$ McCartney, Virginia Immigrants and Adventurers, 1607-1635, A Biographical Dictionary, 606; King James I, "A Counterbalste to Tobacco," in The Workes of the Most High and Mightie Prince James, 215.
} 
success of its colonial venture and the confidence its shareholders felt that Virginia was a potential treasure house. More to the point, by embarking on his program, Sandys was staking the Company's future that the Peace of Pocahontas, negotiated five years earlier, would last. The incentive that Sandys offered to prospective settlers, however, would have been sure to displease Opechancanough, which threatened the very peace upon which his venture so heavily depended. New settlers were free to establish new plantations on unoccupied land within five miles of the boroughs of James City, Charles City, Henrico, and Kecoughtan; or within ten miles of any other plantation. Obviously, Sandys either did not take into account or was indifferent to the fact that his land grant to new colonists would threaten Powhatan resources. ${ }^{110}$

Considering the expenses of Sandys' economic diversification project and the fact that he had essentially gambled the Virginia Company's future on its success, the Company's officers could not have seen Opechancanough's attacks on English settlements and plantations as anything other than catastrophic. In the destruction of English vineyards and mulberry groves, many Company investors could have envisioned the demolition of the prosperous future for themselves and Virginia on which Patrick Copland had spoken with such buoyant anticipation in his Bow Church sermon. However, the principle cause for the Privy Council investigation into the Company's management of the Virginia colony in 1623 appears to have been reports of prospective settlers dying of starvation and disease during voyages to North America.

\footnotetext{
${ }^{110}$ Sir Nathaniel Rich, "Draft of Instructions to the Commissioners to investigate Virginia Affairs, April 14, 1623," in Kingsbury ed., The Records of the Virginia Company of London, V. 4, 116; Michael Leroy Oberg, Dominion and Civility: English Imperialism and Native America, 1585-1685, (Ithaca, NY: Cornell University Press, 2003), 69.
} 
The Virginia Company had focused much of its propaganda campaign in the aftermath of Opechancanough's attacks on recruiting new settlers to replace English casualties from the Uprising. However, in its frantic haste to reinforce Virginia's depleted population, the Company appears to have been consistent in its failure to provide ships carrying new colonists with enough food to last the voyage. A packet of letters arriving in England on the Abigail, a ship returning from Virginia, brought alarming reports of the scarcity and poor quality of the rations during the voyage to North America, and widespread famine and disease in the colony. Richard Norwood, who sailed to Virginia as a settler in early 1623 , wrote in a letter to his father that the daily allowance during his voyage for five men was one pound of bread and one quart of porridge. An especially damning indictment of the Company's failure to adequately provision ships bound for Virginia came from Lady Wyatt's letter to her sister, in which she described how she arrived in Virginia sick and undernourished. It is not difficult to imagine the outrage that Lady Wyatt's sister must have felt at the Company, which had subjected its highborn passenger to such privations. Nor is it unreasonable to suppose that she may have shown the letter to an aristocratic, politically-connected acquaintance or two. Those acquaintances, in their turn, might well have wondered at the competence of a company that had allowed a governor's wife to arrive in Virginia in such a woebegone state. ${ }^{111}$

Letters from the Abigail that described the state of the colony revealed that the arrival of sick and half-starved new settlers, combined with the Company's failure to send additional food, served to exacerbate food shortages in the colony while adding

\footnotetext{
${ }^{111}$ Sir Nathaniel Rich, "Notes taken from Letters which came from Virginia in the 'Abigail,' June 19, 1623" in Kingsbury ed., The Records of the Virginia Company of London, V.4, 231-232.
} 
shipboard epidemics to the list of Virginia's travails. Newly-arrived settler Thomas Nicholls, relating the daily misery of life in Virginia, noted that many colonists cursed the Virginia Company for sending them to North America and for persuading them of the plenty that awaited them, concluding that "For all this plenty the poore Tenants would think themselves happy if they had but Butter \& Cheese uppon Festivall dayes." Virginia colonist Samuel Sharp wrote that "The Lord's hand hath ben more heavie by sicknes \& death then by the sword of our Enemyes." Another settler, William Rowsley, summed up the situation in Virginia after the 1622 assault by relating that the colony had "felt the affliction of Warr, sense of sickness and death of a great number of men, likewise among the Cattle for dogge have eaten in this winter more flesh than the men." Several colonists, ranging in rank from Lady Wyatt to indentured servant Thomas Best, included pleas for food, particularly butter and cheese, in their letters to friends and relatives in England. ${ }^{112}$

The Abigail letters provided James I the pretext he needed to order an investigation. London alderman Robert Johnson, a staunch Court Party partisan, petitioned the king's Privy Council for just such an investigation soon after the ship's arrival in April, 1623. A draft of his petition reveals the extent of Johnson's political bias, as he related that Virginia had flourished during the first 12 years of its existence, when the Court Party dominated the Virginia Company. Since the Virginia Party gained control of the Company, and with it management of the colony, corrupt and disorderly Company investors who worked only for personal gain rather than the good of the colony were allowing the plantation to go to ruin, Johnson lamented. In his eagerness to laud the Court

\footnotetext{
${ }^{112}$ Sir Nathaniel Rich, "Notes taken from Letters which came from Virginia in the 'Abigail,' June 19, 1623," in Kingsbury ed., V.4, The Records of the Virginia Company of London, 231-236.
} 
Party's management of the Virginia Company's colonization project, Johnson was decidedly disingenuous in neglecting to mention that the First Anglo-Powhatan War and the Starving Time, times during which Virginia assuredly did not flourish, occurred on the Court Party's watch. ${ }^{113}$

Shortly after receiving Johnson's petition, the royal Privy Council summoned the leaders of the Virginia Company's two factions. After a rancorous meeting with the faction leaders, the Council ordered a Commission of Inquiry to investigate the Virginia Company's finances, conditions in the colony, and "all wronges and injuries done to any of the Adventurers and Planters." The speed with which the Privy Council acted strongly suggests that its members had already decided to examine the Virginia Party's management of the Company and the colony. On May 9, the Privy Council appointed a justice of the Court of Common Pleas, Sir William Jones, to head a seven-man task force that would explore the Company's past business transactions, what funds the Company had received or collected, and how those funds had been spent. The Privy Council also ordered the commission to scrutinize Virginia's government for instances of malfeasance, determine whether unnecessary hindrances to trade within the colony existed, and ascertain the best means of alleviating partisan bickering between the Virginia Party and the Court Party on both sides of the Atlantic. The commission would report directly to the Privy Council, and had the authority to send for all documents relevant to the investigation and to examine witnesses under oath. ${ }^{114}$

\footnotetext{
${ }^{113}$ Alderman Robert Johnson, "Rough Draught to a Comission \& the Peticon to His Majesty, April (?), 1623," in Kingsbury ed., The Records of the Virginia Company of London, V.4, 85.

${ }^{114}$ The Privy Council of James I, "Act 98, Whitehall, 17 April, 1623," in Acts of the Privy Council of England. Colonial Series. Volume I. AS.D. 1613-1680, W.L. Grant and James Munro ed.., (Hereford: Anthony Brothers, Limited, 1908), 58-59, The Privy Council of James I, "Act 103, Whitehall, 22 May, 1623," in Grant and Munro ed., Acts of the Privy Council of England, 64-65; Craven, The Virginia
} 
Johnson's petition to the Privy Council is likely to have been based on the king's known antipathy toward the Virginia Party in general and Sir Edwin Sandys in particular. He could well have hoped that an investigation of the Virginia Party's administration of the Company and the colonial venture that had such national significance would lead to a scandal that would allow his own Court Party to resume control of the Company. But Sandys and other Virginia Party leaders gained a concession from the Privy Council that the investigation would begin with Sir Thomas Smythe's administration. This insistence on an exploration of the Court Party's management of the Virginia Company could easily have been a vindictive effort on Sandys' part to drag his rivals into disgrace with him. Certainly, the Privy Council could not have failed to notice the discord between the Virginia Company's factions, and may have concluded that the constant in-fighting had compromised the Company's ability to focus on a venture that was far too important to neglect. ${ }^{115}$

The Company's two factions exchanged accusations and counter-accusations throughout the Privy Council's inquiry. The General Assembly of Virginia repudiated Johnson's claim that the colony had prospered under Sir Thomas Smythe's tenure as Treasurer of the Virginia Company, maintaining that Virginia had "remained in great want and misery under most severe and Crewell laws." Several investors, probably Court Party stalwarts, submitted a brief complaint to the commission that accused Sandys of seeking the Treasurer's post to conceal his embezzlement of Virginia Company funds, and of bringing the Company into debt "without any apparent meanes to discharge the

Company of London, 67-69; Herbert Levi Osgood, The American colonies in the seventeenth century, V. 3, (New York: The Macmillan Company, 1907), 43-44.

${ }^{115}$ Craven, The Virginia Company of London, 67. 
same.” The investors also blamed Sandys for the faction-fighting within the Company, not a completely inaccurate charge since Sandys, Southampton and Ferrar founded the Virginia's Company's second faction. Johnson, whose petition to the Privy Council launched the appointment of the Commission of Inquiry for Virginia, prepared a detailed report on "Disorders in the Company and Colony" during the Virginia Party's administration. Foremost among the Company's missteps in the wake of the 1622 Uprising, according to Johnson, was the transportation of new settlers to repopulate Virginia without adequately supplying those settlers with food during their voyage from England or ensuring sufficient housing for new arrivals in the colony. Short food allowances and the overcrowding of ships bound for Virginia had led to shipboard epidemics. Passengers arrived in the colony half-starved, and often died of diseases contracted during the voyage from Europe; but not before infecting others. In less than three years, Johnson wrote, approximately 3,000 colonists had died in Virginia, "for which mortality noe other cause hath yet been shewed but the want of houses, pestring of ships, shortness and badness of food." 116

In his zeal to condemn the Virginia Party's mismanagement of the Virginia Company and its colonial venture, Johnson failed to include Powhatan hostility in his list of contributing factors to the recent high death toll among Europeans in the New World. However, the letters arriving on the Abigail gave Johnson powerful evidence to support his claims of Virginia Party negligence. The aristocratic members of a king's Privy

\footnotetext{
${ }^{116}$ Neill, History of the Virginia Company of London, With Letters to and from the First Colony, Never Before Printed, (Albany, N.Y.: Joel Munsell, 1869), 407; Virginia Adventurers and Planters, "Complaint to His Majesty's Commissioners, May or June (after May 9), 1623," in Kingsbury ed., The Records of the Virginia Company of London, V.4, 173-182.
} 
Council and the Commission of Inquiry would have been particularly swayed by written testimony from the aristocratic wife of a colonial governor, and would have been especially appalled by her account of the conditions under which she traveled to Virginia.

The Commission, having taken charge of the Virginia Company's records, soon discovered that the Company was bankrupt. Correspondence from Virginia painted a bleak picture of the colony's future. And hearings before the Commission of Inquiry demonstrated to the commissioners and the Privy Council that factional strife had hopelessly divided the Virginia Company's house against itself. In the fall of 1623, the Privy Council proposed a new charter for the Company that would place the colony's governing body under the more immediate supervision of the king. According to the terms of the proposed new charter, the king would appoint a governor and 12 assistants, who would manage the Virginia Company and the colony. ${ }^{117}$

When the Privy Council announced the king's intention to remodel the Company and Virginia's government, the Virginia Company replied that the surrender of its existing charter was a matter of such consequence that its members needed a month to consider the proposal and discuss it at the quarterly meeting in mid-November. The Privy Council's demand for the Company's reply to the king's proposal within the week prompted an emergency investors' meeting on October 20,1623, during which only nine members of the 70 who were present voted to surrender the charter. At the regular quarterly meeting on November 19 , only seven investors voted in favor of relinquishing the Company's charter. By this time, the Court of King's Bench had initiated quo

\footnotetext{
${ }^{117}$ The Privy Council of James I, “Act 109, Whitehall, 8 October, 1623," in Grant and Munro ed., Acts of the Privy Council of England, 67-68.
} 
warranto proceedings against the Virginia Company. The case was called up during the Trinity Term of the King's Bench in the spring of 1624, with the king's attorney general Sir Thomas Coventry arguing for the revocation of the Virginia Company's charter on the grounds that it set too few limits on the Company's power in the colony. Somewhat strangely, Coventry's principle concern appears to have been the Virginia Company's power to transport as many Englishmen to Virginia as wished to travel there. Where Donne had proclaimed that Virginia's function as a depository for England's surplus population alone justified its continued existence in his sermon at St. Paul's cathedral two years earlier, Coventry worried that the Company "may in the end carry away all the King's subjects into a foreign land."118

On June 16, 1624, Chief Justice Sir Francis Ley ruled "That the Patent or Charter of the Company of English Merchants trading to Virginia, and pretending to exercise a power and authority over his Majestys good subjects there, should be thenceforth null and void." Ten days later, the Privy Council ordered Ferrar to deliver "all the Patentes, bookes of account, together with the invoises concerning the late Corporation of Virginia" to the keeper of the Council chest. And James I ushered in Virginia's new era as a royal colony on July 15 when he issued a proclamation appointing 13 commissioners residing in the colony and 13 more living in England to take charge of affairs in Virginia. The king confirmed the national importance of England's colonial ventures in North America, and declared that the Virginia Company's mismanagement was to blame for the

\footnotetext{
${ }^{118}$ Craven, The Virginia Company of London, 68-69; The Privy Council of James I, “Act 109, Whitehall, 8 October, 1623," in Grant and Munro ed., Acts of the Privy Council of England, 68-69; Captain John Bargrave, "A Letter to the Lord Treasurer Middlesex," in Kingsbury ed., The Records of the Virginia Company of London, V. 4, 290-291; Neill, History of the Virginia Company of London, 417.
} 
precarious state of that venture. The Company's program of hastily transporting new settlers to the colony with inadequate supplies in response to the Uprising certainly contributed to the disease and famine that ravaged the colony throughout 1622 and 1623. Moreover, the Company had disappointed the king in his high hopes that Virginia "would pduce many staple and good comodities." Much of the responsibility for Virginia's failure to live up to the king's economic expectations must fall on Opechancanough's violent disruption of Sandys' economic diversification program in the colony just as it was getting properly underway, but James I laid the culpability squarely on the Company's doorstep. Government of the colony through a locally-elected General Assembly, James believed, was inherently inefficient because it placed Virginia's affairs in too many hands and had caused "much contencon and confusion." A body of counselors, nominated by himself, had governed the colony in Virginia's first 12 years, in accordance with "our most prudente and princely instruccons given in the beginyng of the plantacon." That form of government, the king declared, had been more effective than the more democratic form of government that the Virginia Party had set up during its control of the Virginia Company, and Virginia as a royal colony would return to that system forthwith. Among the councilors appointed were Sir Thomas Smythe, the recently knighted Sir Samuel Argall, and Alderman Johnson; all former Virginia Company investors who had been prominent members of the Court Party. Sandys, Nicholas Ferrar, and Southampton were not nominated. The Virginia Company's demise meant the end of 
the Virginia Party, while the king integrated Court Party leaders into new management positions. $^{119}$

King James I had always recognized the importance for England of entering the competition against other European powers, and had always intended to monitor the Virginia Company's activities closely. But he seems to have been patient with the Company's failure to turn Virginia into a profitable venture, so long as the Company's leadership remained compliant to royal suggestions. It was only when the Virginia Party, led by some of the king's more prominent political detractors, came to dominate the Virginia Company that James I began to entertain the idea of revoking the Company's charter. The 1622 Uprising, and the Virginia Company's disastrous response to the attacks, essentially handed James I the justification he sought to end his political rivals' influence over colonial affairs. But if Opechancanough and the Powhatans could claim a victory over the Virginia Company, they would not succeed in their probable objective to contain the Tassantassas. The Virginia colony may have been under new management after 1624 , but the colonists' newly-adopted, two pronged policy of separation from or extermination of Native Americans remained unchanged.

\footnotetext{
${ }^{119}$ Neill, History of the Virginia Company of London, 417; The Privy Council of James I, "Act 122, Greenwich, 24 June (1624)," in Grant and Munro ed., Acts of the Privy Council of England, 78; James I, "Commission to certain Lords of the Privy Council and Others for settling a Government in Virginia, July 15, 1624," in Kingsbury ed., The Records of the Virginia Company of London, V.4, 493.
} 


\section{CHAPTER V \\ LONG-TERM CONSEQUENCES}

\section{Beyond Virginia}

On May 26, 1637, a force of about 160 attackers descended on a fortified settlement on the Mystic River in the newly established English colony of Connecticut. As hundreds of allied troops surrounded the settlement, the main attack force smashed its way through the town's two gates. Defenders inside the fort, disoriented by the surprise attack, barricaded themselves inside their homes or attempted to flee. Those who took refuge in their homes died when attackers burst into one dwelling after another. Those who fled died when their attackers cornered them inside the fort and hacked them to pieces, or rounded them up and summarily butchered them in the swamp outside the walls. The two leaders of the attack set fires at each end of the settlement, which quickly spread until they had consumed the entire compound. ${ }^{120}$

Like Opechancanough's attacks on English settlements in Virginia 15 years earlier, the assault on the Mystic River fort was the result of tensions between English settlers and Native Americans over land usage. Like the Powhatans, the attackers at Mystic River spared neither age nor sex, dragging women and children from their hiding

\footnotetext{
${ }^{120}$ John Grenier, The First Way of War: American War Making on the Frontier, 1607-1814, (Cambridge, UK: Cambridge University Press, 2005), 27.
} 
places under beds to slaughter them. An important difference between the two events is that the defenders at Mystic River were not English colonists, but Pequot Indians. The assault force consisted of 90 Connecticut militiamen under Captain John Mason and 70 Massachusetts troops under Captain John Underhill. Their allies, stationed in the swamp around the fort to intercept escaping Pequot survivors, consisted of about 200 Narragansetts and Mohegans: Native American groups who were traditional rivals of the Pequots. $^{121}$

The Mystic Massacre demonstrated that the two-pronged English policy of extermination of and separation from Native Americans, adopted in Virginia in the wake of the 1622 Uprising, had spread to New England. Extermination efforts at Mystic were so successful, Underhill reported in his account of the attack, that out of 400 Pequots inside the town, "not above five of them escaped out of our hands." Underhill appears to have been aware that some readers of his account would be horrified by the slaughter of women and children, insisting that Christians should have more mercy and compassion. But at times, he wrote, "Scripture declareth women and children must perish with their parents." Mason's account of the attack included similarly pious sentiments, but was far more jubilant in tone than Underhill's. "It was the Lord's Doings," Mason exulted, "and it is marvellous in our Eyes! It is He that hath made his Work wonderful, and therefore ought to be remembred." Connecticut colonist Philip Vincent specifically cited the 1622 Uprising in Virginia as a justification for the eradication of an entire Pequot village. The killing of Indians, Vincent declared, preserved peace in New England "better than our English Virginians were by being killed by them." Both Vincent and Underhill echoed

\footnotetext{
${ }^{121}$ Grenier, The First Way of War, 27-28.
} 
Edward Waterhouse in labeling Native Americans as treacherous and perfidious, and Underhill expanded on this theme by writing that "long forbearance and too much lenity of the English towards the Virginian salvages, had like to have been the destruction of the whole plantation" because Indians would always "abuse the goodness of those that condescend to their rudeness and imperfections." ${ }^{122}$

As had been the case in Virginia after the 1622 Uprising, English colonists in New England concluded that Native Americans were not trustworthy neighbors, and must therefore be either driven westward to make way for European settlement further inland or eradicated entirely. In New England's campaign against the Pequots, colonists affected separation from Native Americans by selling hundreds of prisoners into slavery in the West Indies. Combined with the killing of about 1,500 Pequots by New England colonists and Indian allies in the region, the campaign had reduced the Pequots in number to between 180 and 200. Those survivors, Mason gleefully wrote, offered themselves as vassals to the English in exchange for a bare assurance of their lives. The Narragansets, who had acted as allies to the English throughout the Pequot War, expressed admiration at the efficacy of European weapons, but also expressed alarm at the ruthless nature of European war-making, protesting that "it is too furious and slays too many men." The Narragansets' alarm proved well-founded some 40 years later when the English colonists

\footnotetext{
${ }^{122}$ Captain John Mason, "To the Honourable the General Court of Connecticut," in History of the Pequot War, the Contemporary Accounts of Mason, Underhill, Vincent, and Gardener, Charles Orr ed., (Cleveland: The Helman-Taylor Company, 1897), 35; Captain John Underhill, "News from America, or a late and experimental discovery of New England," in Orr ed., History of the Pequot War, 80-82, Phillip Vincent, "A true relation of the late battle fought in New-England, between the English and Salvages, with the present state of things here," in Orr ed., History of the Pequot War, 103, 110.
} 
of Massachusetts, Plymouth, and Connecticut turned the weapons at which they had marveled against them during Metacom's Rebellion. ${ }^{123}$

An intriguing development after the Pequot War resulted from English fear of perceived Indian treachery. William Bradford, the second governor of Plymouth Colony, wrote that rumors of a general Native American conspiracy against English settlers resulted in an accord between the governments of Massachusetts, Connecticut, and Plymouth to form into an entity known as the United Colonies of New England. The Narragansetts, allies of the English during the Pequot War and accessories to the Mystic Massacre, appear to have become disenchanted with their European neighbors, because Bradford claimed that Narragansett plotting was at the heart of the purported Indian conspiracy against New England. ${ }^{124}$

Shortly after the participating colonial governments signed the Articles of Confederation of the United Colonies of New England, the Narragansett sachem, or chief Minatonomi led a force of between 900 and 1,000 warriors against the less powerful Mohegans, giving the newly-unified New England colonies an occasion to field-test their new alliance. Faced with a choice between their main Native Americans allies in the Pequot War, New England policymakers chose to intervene on behalf of the weaker Mohegans, which undoubtedly alienated the Narragansetts ${ }^{125}$

\footnotetext{
${ }^{123}$ Mason, "To the Honourable the General Court of Connecticut," in Orr ed., History of the Pequot War, 39-40; Underhill, "News from America, or a late and experimental discovery of New England," in Orr ed., History of the Pequot War, 84.

${ }^{124}$ William Bradford, History of Plymouth Plantation, (Boston: The Massachusetts Historical Society, 1856), 417.

${ }^{125}$ William Bradford, History of Plymouth Plantation, 417; Plymouth Colony Records, "The Articles of Confederation of the United Colonies of New England, 1643-1684," in Thorpe ed., The Federal and State Constitutions, V. 1, 19.
} 
The pattern of English encroachment on Native American land and armed Indian resistance to that incursion, established in Virginia and repeated in Connecticut, spread to New England on a large scale in the 1670s. Settlers in New England had not forgotten the 1622 Uprising in Virginia, and the fear of similar uprisings seems to have occupied a prominent niche of their collective mentality. When a Christianized Wampanoag Indian named John Sausaman was killed in Plymouth Colony in late 1674, Puritan minister and author Cotton Mather opined that the three Wampanoags accused of his murder had acted primarily because Sausaman had approached Plymouth's governor, Josiah Winslow, with a report that the Wampanoags and several other Native American groups were plotting coordinated attacks on English settlements, similar to Opechancanough's attacks in Virginia. ${ }^{126}$

The apprehension, trail, and execution of Sausaman's alleged murderers was a challenge to the authority of Metacom, the Wampanoag sachem; the more so because one of his senior councilors, a man known to New England colonists as Tobias, had been among the accused. Not only was the trial of Wampanoags in an English court an affront to Metacom's prerogatives as sachem, it was a miscarriage even of English justice because English law of the late seventeenth century required the testimony of two witnesses to obtain a conviction for murder, and the prosecution could only produce a single Indian who claimed to have been an eyewitness to Sausaman's death. A jury of 12 English settlers and six Christianized "Praying Indians" unanimously sentenced Tobias and his associates to death by hanging, which sentence was carried out on Tobias and his friend June 8, 1674. Tobias' son, the last of the accused to ascend the gallows,

\footnotetext{
${ }^{126}$ Increase Mather and Cotton Mather, The History of King Philip's War, (Albany: J. Munsell, 1862), 49.
} 
was spared his father's fate when the rope broke. Given a chance to save his life, Tobias' son confessed that he had been an onlooker while his father and their friend murdered Sausamon. By coercion, the prosecution had obtained the requisite number of witnesses. Having escaped hanging, Tobias' son was held prisoner in Plymouth for a month before being taken out of the jail and shot. ${ }^{127}$

Metacom must indeed have been preparing for war against his English neighbors even before Sausaman's murder, because his response to the English affront to his sovereignty was too prompt and too well-organized to have been an impulsive act. Within days of the trial and executions at Plymouth, Wampanoags and their Narrangansett allies raided English settlements near Mount Hope, “the seat where Philip was kennell'd with the rest of these horrid salvages." ${ }^{128}$ The Narrangansetts, who had assisted in the extermination of the Pequots as a nation 40 years before, had clearly become thoroughly disenchanted with their former English allies. In the war that followed, both the Wampanoags and the Narrangansetts would suffer essentially the same fate as the Pequots before them. By the end of King Philip's War in 1676, between 2,000 and 3,000 Wampanoags and Narragansetts had been killed or captured, and no more than 100 Narragansetts remained alive and at liberty. The Narragansetts, having allied with Connecticut settlers against the Pequots, had seen for themselves the English game of divide-and-conquer, then had seen the European invaders capitalize on divisions between Native American groups. Ultimately, they felt the full force of the "furious" European style of warfare, and many of those who were not exterminated ended their lives as slaves

\footnotetext{
${ }^{127}$ Nathaniel Philbrick, Mayflower: A Story of Courage, Community and War, (New York: Penguin Books, 2006), 223.

${ }^{128}$ Mather and Mather, The History of King Philip's War, 53.
} 
in the West Indies, where it is possible they met Pequots whom they had helped enslave under similar circumstances some 40 years earlier.

The presence of Christianized Nipmuck Indians in New England demonstrates that some of the region's Puritan settlers had initially attempted to live alongside and assimilate the Native Americans they encountered. Indeed, the incident that sparked King Philip's War was the murder of John Sausaman, whom Mather described as "a godly Indian," who "was wont to curb those Indians that knew not God on the account of their debaucheries." Although Mather wrote of the murdered Sausaman with the reverence accorded a Christian martyr, New England's colonists had little regard and less trust for living Christianized Indians. Complaints of the perceived treachery of Christian Indians like that of Massachusetts Bay colonist Mary Pray to a local militia officer that they "commonly give the Indians noatis (notice) how to escape the English," and that "they are as bad as any other (Indians)," led the Massachusetts Bay General Court of Election to brusquely order about 500 Praying Indians transported to Deer Island in Boston Harbor in October, $1675 .{ }^{129}$

In November, 1675, the members of the Court made it abundantly clear that they expected treachery from the Praying Indians still living in or near English settlements when they ordered them transported to islands in the region and mandated that "none of the said Indians shall presume to goe off the sajd islands voluntarily, upon pajne of death; and it shall be laufull for the English to destroy those that they shall finde stragling off

\footnotetext{
${ }^{129}$ Mather and Mather, The History of King Philip's War, 49; Frederick William Gookin, Daniel Gookin, 1612-1687, Assistant and Major General of the Massachusetts Bay Colony: His Life and Letters and Some Account of His Ancestry, (Chicago, Frederick William Gookin, 1912), 149; Massachusetts Bay General Court of Elections, "Att the seccond Sessions of the Generall Court, held at Boston, the 13th of October 1675," in Records of the Governor and Company of the Massachusetts Bay in New England, V. 5, 16741686, Nathaniel B. Shurtleff ed., (Boston: William White, 1854), 57.
} 
from the sajd places of theire confinement, unlesse taken of by order from authority, and under an English guard.” Almost as an afterthought, the General Court instructed ordered a country treasurer to ensure that the Indians interned on Deer Island were adequately provisioned and sheltered. But after a visit to Deer Island, the Puritan minister John Eliot, whose missionary work had converted many of them to Christianity, reported that there was neither food, firewood, nor building materials for shelter to be found there, and the interned Indians were freezing in threadbare clothing. By the time the General Court ordered detained Praying Indians returned "to their oune plantations, or such lands of the English as may be procured for them," in May, 1676, about half of the Native Americans who had wintered on Deer Island had died of starvation or exposure. ${ }^{130}$

Through forced relocation, the Massachusetts General Court temporarily affected physical separation from Native American groups who had attempted to adopt, if not English culture, then at least English religious practices. The General Court of Elections of Plymouth Colony advocated separation through enslavement of captured Native Americans, and this sentence applied not only to prisoners who had proven to be active combatants against the English during King Philip's War, but also to Indians who had failed to warn colonial governments of Metacom's plans to attack English settlements. The Massachusetts Bay General Court favored extermination of Native Americans who fell into English hands, ruling in September, 1676 that "such of them as shall appeare to

\footnotetext{
${ }^{130}$ Massachusetts Bay General Court of Elections, "Att an Adjormment of the Generall Court of October, held at Boston, the 3rd of November 1675," in Shurtleff ed., Records of the Governor and Company of the Massachusetts Bay, V. 5, 64; Gookin, Daniel Gookin, 1612-1687, 149; Massachusetts Bay General Court of Elections, "Att a Generall Court of Election, held at Boston, the 3rd of May, 1676," in Shurtleff ed., Records of the Governor and Company of the Massachusetts Bay in New England, V. 5, 1674-1686, 60; Philbrick, Mayflower, 263.
} 
have imbrued their hands in English blood should suffer death here, and not be transported into forreigne parts." 131

Edward Waterhouse's recommendations in the diatribe he wrote in the aftermath of Opechancanough's surprise attacks in Virginia had included separation from and dispossession, enslavement, and extermination of Native Americans. It certainly would have gratified him to see so many of his proposals put into practice 50 years after the 1622 Uprising and hundreds of miles from Virginia.

\section{An Epilogue in Virginia}

Opechancanough lived well into his 90s, and appears to have behaved peaceably enough after the Second Anglo-Powhatan War to once again lull his English neighbors into complacency; an impressive accomplishment given the catastrophic impact that the 1622 Uprising had on both the Virginia colony and the Virginia Company. Because of the scarcity of documents from the period, Opechancanough's behavior toward the English between 1632 and 1644 is a matter of speculation. But it is difficult to believe that any posture other than that of abject submission to all English demands would have duped Virginia's government into the belief that Opechancanough was no longer a danger to the colony. His appearance of physical decrepitude seems could easily have helped him maintain an appearance of harmlessness. By 1644, he could no longer walk, and had to be carried on a litter. His eyelids had become so heavy that he could not see,

\footnotetext{
131 "Att the Court of Election held for this Gov'ment att Plymouth, for the Jurisdiction of New Plymouth, the first Day of June, Anno Dom 1675," in Shurtleff ed., Records of the Colony of New Plymouth in New England, Court Orders: V. 5, 1668-1878, (Boston: William White, 1856), 173; Massachusetts Bay General Court of Elections, "Att the Sessions of the Generall Court, specially called, sitting in Boston, the 6th of September, 1676, in Shurtleff ed., Records of the Governor and Company of the Massachusetts Bay in New England, V. 5, 1674-1686, 115.
} 
unless they were raised by his attendants. But he had retained his mental acuity, his organizational ability, and especially his resentment of the Tassantassas. ${ }^{132}$

When Opechancanough coordinated the assaults against Virginia settlements in 1644 that triggered the third Anglo-Powhatan War, it is possible that he had heard rumors of the outbreak of civil war in England, and had decided to take advantage of political disarray across the Atlantic in the belief that King Charles I would be too concerned with his own precarious position on the throne to send reinforcements or supplies to the colony. But although keeping abreast of developments in the enemy camp would have been consistent with Opechancanough's standing as a career war-leader, he did not have to look across the ocean to find internal discord amongst the Tassantassas. Sir John Harvey, who had been appointed governor of Virginia in 1628 , had proven to be wildly unpopular with the colonists for his unjust and arbitrary rule, and with the Council in Virginia for his haughty treatment of its members. In 1635, the Council sent Harvey back to England, accompanied by two of its members, Captain Samuel Mathews and Francis Potts to testify to his misconduct. The king, however, ruled that the Council's accusations were, if not groundless, at least exaggerated. Harvey was restored as governor and returned to Virginia in January, 1637, while Mathews and Potts remained in England under arrest. Harvey quickly made himself even more unpopular than during his first term, ordering the arrest of five Council members on the grounds that they had usurped royal authority in removing him from office. Charles I and the Privy Council responded

\footnotetext{
132 John Ferrar, A Perfect Description of Virginia, Being, a Full and True Relation of the Present State of the Plantation, Their Health, Peace and Plenty, (London: Printed for Richard Wodenoth at the Star under Peter's Church in Cornhill, 1649), 11; Rountree, Pocahontas, Powhatan, Opechancanough, 183; Beverley, The History of Virginia, V.1, 49.
} 
to complaints from colonists and petitions from Mathews and Potts by officially removing Harvey from office, and commissioning Sir Francis Wyatt to return to Virginia for another term as governor. It is possible that Opechancanough hoped to take advantage of political squabbling and its accompanying confusion in the colony, but if so, he waited too long to make his move. By the time he launched his surprise attacks, Sir William Berkeley, Wyatt's replacement, had been in office for two years, and at least some semblance of political stability had returned to the colony in the five years since the end of Harvey's tenure. It is more probable that Opechancanough was aware that his death was approaching, and wanted to make one last gesture of defiance to his longtime English enemies. ${ }^{133}$

Whatever his motivation may have been, Opechancanough's attacks in the spring of 1644 on settlements along the York River and on the south side of the James surprised the Tassantassas as much as his 1622 assaults had. The Powhatans killed some 500 settlers, slaughtered their cattle, and destroyed their crops in the coordinated assault. The 1644 attacks, however, had less of an impact than the 1622 Uprising, partly because there was less interaction between Virginia's colonists and the Powhatans, and partly because Virginia's European population exceeded 8,000 colonists by this time. However, his second series of surprise attacks probably served to reinforce the notion of Native American treachery to settlers throughout North America's English colonies. ${ }^{134}$

\footnotetext{
${ }^{133}$ McCartney, Virginia Immigrants and Adventurers, 372-373; Beverley, The History of Virginia, V.1., 48; Rountree, Pocahontas, Powhatan, Opechancanough, 183-184.

${ }^{134}$ Ferrar, A Perfect Description of Virginia, 11-12; Beverley, The History of Virginia V.1, 41; Cave, Lethal Encounters, 133-134.
} 
After the initial surprise attacks, Opechancanough's forces withdrew into the forests and swamps, not even attempting to harass settlers with sniping attacks as they had done after the 1622 Uprising. The Wayanocks and those Nansemonds who had followed Opechancanough fled their homelands along the James River entirely, and never returned. Berkeley, for his part, acted quickly and decisively, designating militia general William Claiborne to immediately take the offensive against the remnants of the Powhatan confederacy. Claiborne accordingly sent forces up the York to storm Opechancanough's capital at Pamunkey, destroying crops, killing all the fleeing Indians they could catch, and forcing the survivors further inland. Other military expeditions in the summer of 1644 targeted Indian villages along the James and the Chickahominies. Opechancanough himself remained at large until the spring of 1646, when Berkeley, having received word of the mamanatowick's whereabouts from an unnamed source, personally led a party of cavalry that ran down a party of Pamunkeys as they were trying to carry him to safety. ${ }^{135}$

Opechancanough was brought back to Jamestown as a prisoner. Berkeley had thoughts of enhancing his reputation in England by presenting Charles I with a royal captive. In the meantime, Berkeley appears to have made a public spectacle of his prisoner, displaying him to the colonists in exactly the same way that a modern zookeeper would display a dangerous animal that had been hunted down, captured, and caged. Fiercely protective of his dignity to the end, Opechancanough, hearing the sounds of footsteps and animated conversation around him, asked a jailer to lift up his eyelids so he could see the source of the tumult. On discovering that a crowd of colonists had been

\footnotetext{
${ }^{135}$ Rountree, Pocahontas, Powhatan, Opechancanough, 184; Cave, Lethal Encounters, 135.
} 
let into the jail to gawk at him, he truculently sent for Berkeley and scornfully told him that, had their situations been reversed, he would not have so callously exposed him as a show for his people. ${ }^{136}$

Berkeley's plan to send his prisoner to England came to naught when, two weeks after Opechancanough's capture, one of the soldiers assigned to guard the old mamanatowick fatally shot him in the back in a fit of pique. Given that Opechancanough could neither walk nor see, it would have been impossible for Berkeley to pass off the murder as a failed escape attempt, but there is no record of the soldier being disciplined in any way for his action. The Pamunkey weroance Necotowance succeeded Opechancanough and agreed to a peace treaty with Virginia that bound all the tribes formerly of the Powhatan confederacy to leave the land between the James and York Rivers for English habitation, while the land north of the York River was reserved for Native American habitation and hunting grounds. ${ }^{137}$

The treaty ending the Third Anglo-Powhatan War was in keeping with the English policy of affecting separation from their Native American neighbors. But as the white population in North America increased, the settlers pushed their Native American neighbors further into the continent's interior. By 1685, only 2,900 Indians remained in Virginia east of the Blue Ridge Mountains, compared to over 14,000 in 1607, when the first English settlers arrived. ${ }^{138}$

\footnotetext{
${ }^{136}$ Beverley, The History of Virginia, V.1, 50.

${ }^{137}$ Beverley, The History of Virginia, V.1, 49; Virginia General Assembly, "The Peace Treaty That Ended the Anglo-Indian War of 1644-1646," in Billings ed., The Old Dominion in the Seventeenth Century, 280. ${ }^{138}$ Peter H. Wood, "The Changing Population of the Colonial South," in Powhatan's Mantle: Indians in the Colonial Southeast, Revised and Expanded Edition, Gregory A. Waselkov, Peter H. Wood, and Tom Hatley ed., (Lincoln, NE and London: University of Nebraska Press, 2006), 60.
} 


\section{Conclusion}

The slaughter of a significant portion of the Virginia colony's population and the failure of the Virginia Company of London are likely to have been events of immediate consequence in the 1620s. But an overpopulated England was able and willing to replace the colonists killed in the 1622 Uprising, and the dissolution of a joint stock company plainly did not deter the English crown's commitment to make a success of a colonization effort in North America after three failures.

The shift in English attitudes toward Native Americans and the major modification of English policy regarding Native Americans were the most momentous and far-reaching consequences of the 1622 Uprising. When the first English colonists sailed into the Chesapeake Bay and up the James River, they had specific instructions from the Virginia Company not to trust the region's Native Americans, but also to avoid offending them if possible. When the colonists were unable or unwilling to avoid antagonizing the powerful Indian confederacy they encountered, Virginia narrowly avoided becoming England's fourth failed colonial venture in North America. But between the end of First Anglo-Powhatan War and the 1622 Uprising English policy makers on both sides of the Atlantic favored a program of peaceful and cooperative contact between settlers and Native Americans, although the relationship was always to be that of superior and subordinate, with the Anglocentric colonists occupying the superior role. The establishment of Henricus College in 1619 was perhaps the most visible symbol of the cooperation between English settlers and the Powhatans during the Peace of Pocahontas. The Virginia Company of London initially founded the college to evangelize Native Americans and train them to work in trades that would benefit the 
colony. By 1621, however, the Company had considered having the sons of white planters educated at Henricus alongside Native American students as an alternative to sending them to schools in England. ${ }^{139}$

The destruction of the College of Henricus during the Uprising was likely to have been a symbolic gesture of Opechancanough's rejection of English institutions, as well as a rejection of English efforts to incorporate Native Americans into the Virginia colony. Given that his coordinated attacks were mostly on Virginia's outlying settlements and plantations, and Powhatan tactics against English colonists were limited to hit-and-run raids, it seems likely that Opechancanough's intent was to curtail English encroachment on Native American croplands and hunting grounds. Certainly, the Uprising represented the destruction of English hopes to assimilate Native Americans into Virginia's social order. Following the Second Anglo-Powhatan War, all English hopes of an interracial society in Virginia vanished. Mistrust of Native Americans dominated Anglo-American thinking after 1622, and that suspicion inspired a program of almost total separation from and incessant enmity toward Indians. Colonial officials tolerated the presence in their settlements of Native Americans who had converted to Christianity or displayed complete subservience to Anglo-American culture. But as the internment of Praying Indians on Deer Island during King Philip's War proved, English colonists were skeptical of even the most cooperative Native Americans. ${ }^{140}$

\footnotetext{
139 "At a Meeting of the Committee on Tuesday, the $30^{\text {th }}$ of October, 1621, in Kingsbury ed., Records of the Virginia Company of London, V. 1, 538.

${ }^{140}$ Vaughan, "'Expulsion of the Salvages': English Policy and the Virginia Massacre of 1622," 58; Thomas Nelson Page, The Old Dominion, Her Making and Her Manners, (New York: Charles Scribner's Sons, 1910), 149.
} 
American historian J. Frederick Fauzs referred to the 1622 Massacre as the first terrorist attack in Anglo-America, noting that terrorism may not have entered the English language until the end of the eighteenth century, but the concept of calculated violence against citizens of an enemy power with the intent of making noncombatants experience the suffering that their society had inflicted on others was far from unknown to seventeenth century Europeans. The 1605 Gunpowder Plot, in which a group of English Catholics attempted to assassinate King James I by blowing up the House of Lords while Parliament was in session, has recently received recognition as England's first modern terrorist conspiracy. ${ }^{141}$ Opechancanough's attacks on English settlements in Virginia qualify as an act of terrorism not only because they were planned assaults on noncombatants, but because they created the same sense of devastation and fury that survivors of modern terrorist attacks often experience.

As is often the case in the aftermath of modern terrorist raids, a call for revenge accompanied the anger that English policymakers felt in the wake of the 1622 Uprising. In response to Wyatt's news of the attacks, the Virginia Company's Treasurer and Council for Virginia excoriated the Powhatans as "ungratefull to all benefit, and uncapable of all goodness.” and ordered Sir Francis Wyatt to pursue all possible means to exact such a "sharp revenge uppon the bloody miscreants," as to erase them from the face of the earth, or at least expel them from Virginia. Clearly, the seventeenth century notion

141 J. Frederick Fausz, "The First Act of Terrorism in English America,” History News Network, 1-11-06, accessed January 30, 2016, http://historynewsnetwork.org/article/19085\#. 
of English justice demanded that the Powhatans be punished as severely as modern state actors demand that the sponsors of present-day terrorist incidents be chastised. ${ }^{142}$

In the late sixteenth century, Richard Hakluyt had held up agents of Spanish colonization in the New World as examples of how Europeans should not behave toward Native Americans. Indian victims of Spanish atrocity were "lambes," torn apart by Spaniards who fell upon them "as wolves, as lyons, and as tygers moste cruell." After the 1622 Uprising, Native Americans had themselves become, in Christopher Brooke's estimation, "wolves," "tygars," and "no better than a heard of beasts." Where Hakluyt had abhorred Spanish cruelty, Waterhouse admired Spanish persistence in establishing and securing New World possessions in spite of the "calamities and mischiefs" that Indians visited upon them. ${ }^{143}$

Edward Waterhouse, an otherwise obscure figure who disappears from historical records after writing "A Declaration of the State of the Colony and Affaires in Virginia," had a major impact on the shaping of Anglo-American doctrine regarding Native Americans. Indians would be steadily dispossessed throughout the next 150 years so that "their cleared grounds in all their villages which are situate in the fruitfullest places of the land shall be inhabited by us." 144 Throughout the English colonies, white settlers and Indians withdrew to separate locales, and as colonial populations expanded, white

\footnotetext{
${ }^{142}$ Treasurer and Council for Virginia; "Letter to Governor and Council in Virginia, August 1, 1622," in Kingsbury ed., The Records of the Virginia Company of London, V. 3, 672; Virginia Company, "A Letter to the Governor and the Council in Virginia, October 7, 1622," in Kingsbury ed., The Records of the Virginia Company of London, 683.

${ }^{143}$ Hakluyt, Woods, and Deane, A Discourse Concerning Western Planting, 72; Brooke, "A Poem on the Late Massacre in Virginia," 275-276; Waterhouse, "A Declaration of the State of the Colony and Affaires in Virginia," in Kingsbury ed., The Records of the Virginia Company of London, 560-561.

${ }^{144}$ Waterhouse, "A Declaration of the State of the Colony and Affaires in Virginia," in Kingsbury ed., The Records of the Virginia Company of London, V. 3, 557; King George III, The Royal Proclamation, October 7, 1763, (Calgary, AB: Canadian Constitution Foundation, 2015), 5.
} 
encroachment would steadily dispossess Native Americans of more of their hunting grounds and croplands until the Royal Proclamation of 1763 created a boundary line between the British colonies and Native American lands at the Appalachian Mountains, forbidding colonial governments to grant warrants of survey or land patents in land reserved for Indian hunting and habitation. And after the Revolutionary War ended the British colonial presence in what is now known as the United States rendered the Proclamation of 1763 null and void, the boundaries between white settlement and Native American homelands were pushed relentlessly further west. The process that ended with Indians being forced onto reservations as the United States expanded to the Pacific Ocean began on the morning of March 22, 1622. 


\section{REFERENCES}

$103^{\text {rd }}$ U.S. Congress, Public Law 103-308, Aug. 3, 1994, “Joint Resolution Designating December 7 of each year as 'National Pearl Harbor Remembrance Day."'

Alford, Henry ed., The Works of John Donne, D.D., Dean of St. Paul's, 1621-1631, With a Memoir of His Life, V. 6, ed. Henry Alford, (London: John W. Parker, 1839).

Barbour, Philip L. ed., The Jamestown Voyages Under the First Charter, 1606-1609, (Cambridge, U.K, The Hakluyt Society, 1969).

Beverley, Robert, The History of Virginia, in Four Parts, reprinted from the author's second revised edition, 1722, (Richmond, VA.: J.W. Randolph, 1855).

Billings, Warren M., The Old Dominion in the Seventeenth Century: A Documentary History of Virginia, (Chapel Hill, N.C.: University of North Carolina Press, 1975).

Bradford, William, History of Plymouth Plantation, (Boston: The Massachusetts Historical Society, 1856).

Brooke, Christopher, "A Poem on the Late Massacre in Virginia," The Virginia Magazine of History and Biography, V. 72, No. 4 (July, 1964), 270-291.

Caughey, John W., Franklin, John Hope, and May, Ernest R., Land of the Free: A History of the United States, (New York: Benzinger, Inc., 1966).

Cave, Alfred A., Lethal Encounters: Englishmen and Indians in Colonial America,

(Lincoln, NE: University of Nebraska Press).

Chandler, Julian Alvin Carroll, Makers of Virginia History, (New York, Atlanta, Boston, Dallas, Chicago: Silver, Burdett and Company, 1904).

Copland, Patrick and Pope, Peter, Virginia's God be thanked, or A sermon of thanksgiving for the happie success of the affayres in Virginia this last yeare, (London: William Sheffard and John Bellamy, 1622).

Craven, Wesley F., The Virginia Company of London, 1606-1624, (Baltimore: Genealogical Publishing Co., Inc., 2004).

Custalow, Linwood, and Daniel, Angela L., The True Story of Pocahontas: The Other Side of History, (Golden, Colo.: Fulcrum Publishing, 2007).

Divine, Robert A., Breen, T.H., Fredrickson, George M., Williams, R. Hal, Gross, Ariela J., and Brands, H.W., The American Story, Third Edition, (New York, San Francisco, Boston, London, Toronto, Sydney, Tokyo, Singapore, Madrid, Mexico City, Munich, Paris, Cape Town, Hong Kong, Montreal: Pearson Education, Inc., 2007).

Fausz, J. Frederick, "The First Act of Terrorism in English America," History News Network, 1-11-06, accessed January 30, 2016, http://historynewsnetwork.org/article/19085\#.

Fausz, J. Frederick, "The Missing Women of Martin's Hundred," American History, V. 33, No. 1 (March, 1998), 56-62.

Ferrar, John, A Perfect Description of Virginia, Being, a Full and True Relation of the 
Present State of the Plantation, Their Health, Peace and Plenty, (London: Printed for Richard Wodenoth at the Star under Peter's Church in Cornhill, 1649).

Garrett, W.R., "The Father of Representative Government in America," American Historical Magazine, V. 1, No. 1 (January, 1896), 3-21.

Gleach, Frederic, Powhatan's World and Colonial Virginia: A Conflict of Cultures, (Lincoln, NE: University of Nebraska Press, 1997).

Gookin, Frederick William, Daniel Gookin, 1612-1687, Assistant and Major General of the Massachusetts Bay Colony: His Life and Letters and Some Account of His Ancestry, (Chicago, Frederick William Gookin, 1912).

Grant, W.L. and Munro, James ed., Acts of the Privy Council of England. Colonial Series. Volume I. AS.D. 1613-1680, (Hereford: Anthony Brothers, Limited, 1908).

Grenier, John, The First Way of War: American War Making on the Frontier, 1607-1814, (Cambridge, U.K.: Cambridge University Press, 2005).

Haile, Edward Wright ed., Jamestown Narratives: Eyewitness Accounts of the Virginia Colony, the First Decade, (Champlain, VA., RoundHouse, 1998).

Hakluyt, Richard, Woods, Leonard and Deane, Charles, A Discourse Concerning Western Planting, Written in the Year 1584, (Cambridge, UK: John Wilson and Son, 1877).

Hamor, Ralph, A True Discourse of the Present State of Virginia, (Richmond, Va.: The Virginia State Library, 1957).

Horn, James, A Land as God Made It: Jamestown and the Birth of America, (New York: Basic Books, 2005).

Johnson, Paul, A History of the American People, (New York: HarperCollins Publishers, 1997).

Johnson, Robert, Nova Brittania. Offering Most Excellent Fruits by Planting in Virginia. Exciting All Such as be Well Affected to Further the Same, (New York: J. Sabin, 1867).

King George III, The Royal Proclamation, October 7, 1763, (Calgrary, AB:

Canadian Constitution Foundation, 2015).

King James I, The Workes of the Most High and Mightie Prince James by the Grace of God, King of Great Britaine, France and Ireland, Defender of the Faith, \&c, (London: Robert Barker and John Bill, 1616).

Kingsbury, Susan Myra ed., The Records of the Virginia Company of London, V. 1-4, (Washington, D.C.: Government Printing Office, 1906).

Lee, Sir Sidney ed., The Dictionary of National Biography, V.6, 49, (London: Smith, Elder \& Co, 1899).

Mather, Increase and Mather, Cotton, The History of King Philip's War, (Albany: J. Munsell, 1862).

McCartney, Martha W., Virginia Immigrants and Adventurers, 1607-1635, A Biographical Dictionary, (Baltimore: Genealogical Publishing Company, 2007).

McIlwaine, H.R. ed., Minutes of the Council and General Court of Colonial Virginia: 1622-1632, 1670-1676: With Notes and Excerpts from Original Records and General Court Records, Into 1683, Now Lost, (Richmond, VA: Virginia State Library, 1924).

McKinley, Janie Mae Jones, The Cultural Roots of the 1622 Indian Attack: Richard Pace and Chanco Save Jamestown, (Silva, NC.: Catch the Spirit of Appalachia, Inc., 
2011).

National Park Service, "Pocahontas: Her Life and Legend," Historic Jamestowne, accessed February 19, 2016,

http://www.nps.gov/jame/learn/historyculture/pocahontas-her-life-andlegend.htm.

Neill, Edward Duffeild, History of the Virginia Company of London, With Letters to and from the First Colony, Never Before Printed, (Albany, N.Y.: Joel Munsell, 1869).

Neill, Edward Duffield, Memoir of Rev. Patrick Copland, Rector Elect of the First

Projected

College in the United State, (New York: Charles Scribner \& Co., 1871).

Nye, Eric, "Pounds Sterling to Dollars: Historical Conversion of Currency," (University of Wyoming), accessed January 19, 2016, http://www.uwyo.edu/numimage/currency.htm.

Oberg, Michael Leroy, Dominion and Civility: English Imperialism and Native America, 1585-1685, (Ithaca, NY: Cornell University Press, 2003).

Orr, Charles ed., History of the Pequot War, the Contemporary Accounts of Mason, Underhill, Vincent, and Gardener, (Cleveland: The Helman-Taylor Company, 1897).

Orton, Mark C., and Strong, Thomas ed., Colonial Records of Virginia, (Richmond, Va., R.F. Walker, Superintendent Public Printing, 1874).

Osgood, Herbert Levi, The American colonies in the seventeenth century, $V .3$, (New York: The Macmillan Company, 1907).

Page, Thomas Nelson, The Old Dominion, Her Making and Her Manners, (New York: Charles Scribner's Sons, 1910).

Philbrick, Nathaniel, Mayflower: A Story of Courage, Community and War, (New York: Penguin Books, 2006).

Price, David A., Love and Hate in Jamestown: Pocahontas, John Smith, and the Start of a New

Nation, (New York: Vintage Books, 2005).

Prothero, G.W. ed., Select Statutes and Other Constitutional Documents Illustrative of the Reigns of Elizabeth and James I, Third Edition, (London, Edinburgh, New York and Toronto: Oxford at the Clarendon Press, 1906).

Purchas, Samuel, Haklutus Posthumus: or Purchas His Pilgrimes, V. 5, No. 19, (London, New York, Toronto: Macmillan and Co., Ltd., 1906).

Purchas, Samuel, The kings tovvre and triumphant arch of London. A sermon preached at Pauls Crosse, August. 5. 1622, (London: W. Stansby, 1623).

Rorabaugh, William J., Critchlow, Donald T., and Paula Baker, America's Promise: A Concise History of the United States, (Lanham, UK, Boulder, CO, New York, Toronto, Oxford: Rowman and Littlefield Publishers, Inc., 2004).

Rountree, Helen C., Pocahontas, Powhatan, Opechancanough, Three Indian Lives Changed by Jamestown, (Charlottesville, VA: University of Virginia Press, 2005).

Rountree, Helen C., The Powhatan Indians of Virginia, Their Traditional Culture (Norman, OK: University of Oklahoma Press, 1989).

Sainsbury, W. Noel Sainsbury ed., Calendar of State Papers, Colonial Series, 1574-1660, America and West Indies, V. 5, (London: Longman, Green, Longman, \& Roberts, 1860). 
Seavoy, Ronald, An Economic History of the United States: From 1607 to the Present, (NewYork: Taylor \& Francis Group, 2006).

Shurtleff, Nathaniel B., Records of the Colony of New Plymouth in New England, Court Orders: V. 5, 1668-1878, (Boston: William White, 1856).

Shurtleff, Nathaniel B. ed., Records of the Governor and Company of the Massachusetts Bay in New England, V. 5, 1674-1686, (Boston: William White, 1854).

Smith, John, The Generall Historie of Virginia, New England \& The Summer Isles, Together with the True Travels, Adventures and Observations, and a Sea Grammar, (Glasgow: James MacLehose and Sons, 1907).

Smith, John, A True Relation of Such Occurrences and Accidents of Note as Happened in Virginia, (Boston: Wiggin and Lunt, 1866).

Stith, William, The History of the First Discovery and Settlement of Virginia: Being an Essay towards the General History of this Colony, (Charlottesville, VA: Reprint Company, 1747).

Strachey, William, The Historie of Travaile Into Virginia Britannia; Expressing the Cosmographie and Comodities of the Country, Together With the Manners and Customes of the People, (London: The Hakluyt Society, 1849).

Thorpe, Francis Newton ed., The Federal and State Constitutions Colonial Charters, and Other Organic Laws of the States, Territories, and Colonies Now or Heretofore Forming the United States of America, V.1, 7, (Washington, D.C.: Government Printing Office, 1909).

Vaughan, Alden T., "'Expulsion of the Salvages': English Policy and the Virginia Massacre of 1622," The William and Mary Quarterly, Third Series, V. 35, No. 1 (Jan., 1978), 57-84.

Waselkov, Gregory A., Wood, Peter H., and Hatley, Tom ed., Powhatan's Mantle: Indians in the Colonial Southeast, Revised and Expanded Edition, (Lincoln, NE and London: University of Nebraska Press, 2006).

Wheeler, William Bruce; Becker, Susan; and Glover, Lorri, Discovering the American Past: A Look at the Evidence, Volume I: to 1877, Seventh Edition, (Boston: Wadsworth, Cengage Learning, 2012).

Wooley, John and Peters, Gerhard ed., The American Presidency Project, 2014, (University of California, Santa Barbara, 2014), accessed February 3, 2016, http://www.presidency.ucsb. 